\title{
Lise ve Üniversite Öğrencilerinin Medya Araçları Kullanımlarının Karşılaştırmalı Analizi
}

$\ddot{O} z$

Özgür KIRAN*

Gelişen iletişim teknolojilerinin yaygın kullanımına bağlı olarak hızlı bir toplumsal değişim süreci yaşanmaktadır. İletişim araçları küresel dünyanın birey ve toplumların gözünde giderek küçülmesine, zaman ve mekân algılarının farklılaşmasına, kendileriyle diğer toplum ve kültürleri kıyaslamalarına daha fazla ve kolay olanaklar sunmaktadır. İletişim araçları insanlık tarihinin farklı dönemlerinde birçok değişikliğe uğrayarak günümüze kadar oldukça gelişmiş ve gelişmeye de devam etmektedir. Ancak kitle iletişim araçlarının gelişim hızı son yüzyıllık sürede tarihin hiçbir döneminde olmadığ kadar hızlı yaşanmış ve doğal olarak bu hızlı değişim toplumları da aynı yönde etkilemişsir. Endüstri devriminden itibaren teknoloji, ulaşımdan haberleşmeye, sağlıktan eğitime hayatın hemen her alanında geçmişe kıyasla oldukça hızlı değişimlere yol açarken iletişim teknolojileri genel anlamdaki bu teknolojik gelişmelerin en önemli yansıma alanlarından birisini oluşturmaktadır. Bu araştırma Sinop ilinde 2018-2019 eğitim öğretim yılında öğrenime devam eden üniversite ve lise öğrencileri üzerinde yürütülmüștür. Öğrencilere geleneksel medya araçları olarak televizyon ve gazete, yeni medya araçları olarak da internet ve sosyal medya ile ilgili sorulardan oluşan bir anket formu uygulanmıştır. Araştırma sonucuna göre her iki öğrenim düzeyindeki gençler arasında internet ve sosyal medya kullanımının yaygın olduğu, gazete okuma alışkanlıklarının ise oldukça düşük olduğu tespit edilmiştir. Her iki öğrenim türündeki gençler arasında sosyal medya kullanım oranı yüksek bulunmuştur. Medyanın hem teknolojik hem de içerik olarak kendisini hızlı geliştirdiği günümüzde bireyler üzerindeki her türlü etkisi aynı oranda sıklıkla takip edilmelidir. Bu kapsamda genç kitlenin dışında aileler, yetişkinler hatta yaşlılar üzerinde de medya kullanımlarına ilişkin araştırmalarla konunun genişletilmesi önem arz etmektedir.

Anahtar Kelimeler: Gençlik, Medya, Sosyal Medya, İletişim Sosyolojisi.

\section{Comparative Analysis of Media Tools Usage of High School and University Students \\ Abstract}

Due to the widespread use of developing communication technologies, there is a rapid process of social change. Communication tools are increasingly shrinking the global world in the eyes of individuals and societies and differentiating perceptions of time and space. This situation offers more and easier opportunities to compare themselves with other societies and cultures. Communication tools have undergone many changes in different periods of human history and have improved considerably. However, the speed of development of mass media has reached its highest level in the last century. This rapid change has affected societies in the same direction. Since the industrial revolution, technology has caused rapid changes in almost every field of life from transportation to communication, from health to education, while communication technologies generally constitute one of the most important reflection areas of these technological developments. This research was carried out on university and high school students who continue to study in the 2018-2019 academic year in Sinop city center. Students were implemented a survey of questions about traditional media tools and new media tools. According to the results of the research, have been found that the use of the internet and social media is widespread among young people at both levels of education, while the habits of reading newspapers are quite low. The rate of social media usage has been found to be high among young people in both education types. Today, when the media is developing itself both technologically and in terms of content, its effects on individuals should be followed closely. In this context, it is important to broaden the subject with researches on the use of media on families, adults and even the elderly, just like young people.

Key words: Youth, Media, Social Media, Communication Sociology.

Geliş/Received: 23.11 .2020

Kabul/Accepted: 22.06 .2021

* Bu çalışma için, yazarların 22.02.2018 tarihli başvuru dilekçesiyle Sinop Üniversitesi İnsan Araştırmaları Etik Kurulu'ndan 26.02.2018 tarih ve 2018/22 sayılı karar ile etik kurul izni alınmıştır.

\footnotetext{
* Dr. Öğr. Üyesi, Samsun Üniversitesi, İİSBF, Sosyoloji Bölümü, ozgur.kiran@ @amsun.edu.tr, Orcid : 0000-00016354-6076

(Makale Türü: Araştırma makalesi)
} 


\section{Giriş}

Yüzyıllar boyunca icat edilmiş tüm araç gereçler mevcut sosyo-kültürel, ekonomik ve siyasal yapılar üzerinde az ya da çok etkili olmuş, bu anlamda bireysel ve toplumsal tutum ve davranışlarda da değişikliğe yol açmıştır (Aksaçlığlu ve Yılmaz, 2007: 7). İletişim araçları da tarihsel süreçte bir önceki dönemine göre giderek artan hızda geliştirilmiş ancak tarihin hiçbir döneminde özellikle son yüzyıllık sürede olduğu kadar hızlı bir değişme ve gelişme göstermemiştir. Doğal olarak bu hızlı değişim ve gelişim aynı doğrultuda toplumları da etkilemiştir.

Endüstri devriminden itibaren teknoloji ulaşımdan haberleşmeye, sağlıktan eğitime hayatın hemen her alanında geçmişe kıyasla oldukça hızlı değişimlere yol açarken kitle iletişim teknolojileri, bu değişimlerin en önemli yansıma alanlarından birisini oluşturmuştur. İletişim teknolojileri içerisindeki her yeni araç önceki versiyonlarından daha kısa sürede yerini almaktadır. $\mathrm{Bu}$ durum teknolojik araçların sadece maddi yönlerindeki değişimleri için değil işlevsel yönlerindeki değişimler için de geçerlidir. Örneğin televizyon teknolojisi gelişirken giderek kanal çeşitliliği de artmış, bu artışla birlikte program içerikleri de çeşitlenmiş hatta tematik yayın yapan kanallar ortaya çıkmıştır. Aynı örnek, haberleşmede kullandığımız telefonlar için de verilebilir. Santralli, kablolu, manyetolu telefon teknolojisinden günümüz akıllı telefon teknolojisine gelene kadar birçok ara teknolojik sistemler geliştirilmiş ve her biri öncekinden daha kısa süre de geliştirilmiştir. Telefon başlangıçta bir alet olarak yalnızca haberleşme amacıyla kullanılırken, günümüzde bunun çok ötesine geçerek haberleşme dişında gerek duyabileceğimiz birçok teknolojik aletin özelliğini de içinde barındırır hale gelmiştir.

Bireyler medya içeriklerinin tüketiminde bilinçli tercihler yaptıklarında gereksinimlerini karşılayabilirler. Fakat tersi durumlarda medyanın zararlı içeriklerine maruz kalma olasılıkları da artacaktır. Bu anlamda gerek birey gerekse ailesi bakımından hangi kitle iletişim aracını ne için ve ne süreyle kullanmaları gerektiği oldukça önemlidir (Aytemiz, 2011: 11-12). İnternetin sağlıklı kullanımında birey için, belli bir hedef doğrultusunda, uygun koşullar altında ve zamanın doğru kullanımı önemlidir. Sağlıksız internet kullanımında ise hem bireyin kendisinin hem de çevresinin yaşamında psiko-sosyal ve bilişsel güçlükler ortaya çıkması söz konusudur (Çetin Dağlı ve Gündüz, 2017: 340). Sağlıklı internet kullanımı; istediği hedefe ulaşmak isteyen bireyin, herhangi bir biçimde ve herhangi bir rahatsızlık duymadan birey için uygun zamanda interneti kullanmasıdı (Davis, 2001). Bunun tersi olan sağlıksız internet kullanımı ise, internet kullanımının bireyin önce kendi ve daha sonra çevresinin yaşamında psikolojik, sosyal ve bilişsel alanlarda güçlükler oluşturmasıdır. Başka bir ifadeyle, sorun, internetin ebeveynlerin, akranların, komşuların ve akrabaların kısacası var olan sosyal çevrenin yerini almasıdır. 
Medya alanında iki önemli düşünür olarak kabul edilen McLuhan ve Baudrillard kuramsal anlamda birbirlerinden farklı düşünürlerken ${ }^{\dagger}$ birleştikleri en önemli nokta "teknolojik determinizm"dir. Yani toplumsal gerçekliğin teknolojik gelişmeler temel alınarak açıklanmasıdır. $\mathrm{Bu}$ anlamda teknoloji toplum üstü bir unsurdur ve teknolojik gelişmeler karşısında insan pasif durumdadır (Baban, 2012: 60-61). Günümüzün iletişim kültüründe nesnel dünyaya ait sayısız kaynak bulmak mümkündür. Bu anlamda önemli olan bize sunulan mesajların fikirlerimizi hangi yönde etkileyeceğini tespit etmek veya mesajlarda sunulan bilginin içeriğinin doğru olup olmadığını saptamaktır (Jols ve Thoman, 2008: 12).

\section{Medya \\ Medya şüpheye yer vermeyecek derecede hayata bakışımızda, anlayış ve} davranışlarımızda son derece etkili olan bir güçtür. Hem geleneksel hem de yeni medya araçları açısından bakıldığında maruz kaldığımız medya mesajları bizden öncekilerle kıyaslanmayacak derecede yoğundur (Jols ve Thoman, 2008: 14). Medyadaki bu yoğun mesaj bombardımanından bireylerin -özellikle çocuk ve gençlerin- etkilenmeleri kaçınılmazdır.

Medya özellikle genç bireylerin bilgi, eğlence, moda, arkadaşl1k, cinsellik, evlilik, yaşam tarzı vb. konularına bakış tarzlarını şekillendirmede ön plandadır. Tüm dünyada olduğu gibi ülkemizdeki bireylerin de önemli bir kısmı geleneksel veya yeni medya araçlarından birini/birkaçını kullanarak habere, bilgiye ulaşma, eğitim ve eğlence gibi birtakım ihtiyaçlarını gidermektedirler. Üstelik bu süreçte dijital medya bu imkanlara erişim kolaylığı sağlarken daha ekonomiktir ve yayılma hızı da oldukça fazladır (Bilici, 2017: 2-8). Medyanın insanlar üzerindeki etkisi oldukça gizli, yavaş ve farkında olmadan işlemektedir (Şahin, 2018: 19). Benliğimizi tümüyle esir alan medya özel yaşantımızı her yönüyle kapsamlı bir şekilde etkilemektedir. Bu anlamda medyanın, bireyler olarak ortamlarımızı hangi yollarla ve ne şekilde meydana getirdiğini incelemeden sosyo-kültürel değişimin hiçbir tarafını kavrayamayız (Fiore, 2019: 26). Günümüz gençliğinin maruz kaldığı yabancılaşma, şiddet, cinsel tutkuya aşırı yönelim, zararlı madde kullanımı, ilgisizlik ve amaçsızlık içeren davranışlarının altında medya araçlarının etkisi oldukça fazladır (Can, 2015: 238).

\section{Geleneksel Medya}

Geleneksel medyanın mesaj akışı, yayıncı bir kuruluştan geniş kitlelere yayılacak şekilde ve tek yönlüdür (Bilici, 2017: 8). Geleneksel medya araçları olarak kabul edilen araçların başında radyo ve televizyon gelmektedir. 1900'lü yılların başında radyo son derece güçlü bir propaganda aracı olarak kullanılmıştır. Onu takip eden televizyon ise görsellik niteliğinin eklenmesiyle birlikte toplumların yaşamında daha hızlı değişimleri beraberinde getirmiştir. Hem uzakları yakın

\footnotetext{
$\dagger$ McLuhan medyayı güçlü, belirleyici, özerk ve aktif bir özne kabul ederken, Baudrillard medyayı bir nesne olarak ele almakta ve medyanın bir kullanım değeri olmadığını ifade etmektedir (Baban, 2012: 60).
} 
Özgür KIRAN

Lise ve Üniversite Öğrencilerinin Medya Araçları Kullanımlarının

Karşılaştırmalı Analizi

ederken hem de farklı kültürlerin birbirini tanımasını, benzerlik ve farklılıklarını ortaya koymuştur. Toplumdaki her yaş kategorisini etkileme özelliği olmasının yanı sıra çocuk ve gençler üzerindeki etkisinin daha fazla olduğu söylenebilir. Arslan'a göre (2006) televizyon, hedef kitlesinde en fazla çocuklara etkide bulunurken bu etkilerinin başında genel olarak dersleri, sosyal gelişimleri, fizyolojik gelişimleri, psikolojik gelişimleri ve cinsel gelişimleri gelmektedir.

\section{Yeni Medya}

Günümüzde kullanım yoğunluğunun gitgide artması ve adeta bedenin bir uzvu durumuna gelmesiyle beraber bilgisayarlar, oyun konsolları, mobil cep telefonları, dijital kameralar, internet uygulamaları, MP3 çalarlar, dijital televizyonlar ve benzerleri yeni medya olarak nitelendirilebilir (Binark, 2007: 21; Laughey, 2010: 158). İnternette sosyal paylaşım imkânı veren sitelerin çoğalmasıyla bunun bireysel katılıma da uygun olması yeni medyanın aynı zamanda sosyal medya olarak ifade edilmesini sağlamıştır (Ünür, 2016: 156). İçerik oluşumunda izleyici katkısının olması yeni medyayı geleneksel medyadan ayıran en önemli özelliklerden birisidir. Geleneksel medya tek yönlü bir iletişim olanağı sunarken internet temelli yeni medya iletişimi çift yönlü hale getirerek iletişim olgusuna yepyeni bir boyut kazandırmıştır. Frechette'e göre internet gündelik hayatta birçok kolaylık sağlarken aynı zamanda kimlik hırsızlı̆̆ının, pornografinin, ırkçılığın, dilin kötü kullanımının ve benzeri birçok risk ve sorunların da ortaya çıkmasına yol açmıştır (Frechette'den aktaran; Bilici, 2017: 17).

\section{Sosyal Medya}

3G teknolojisi sayesinde iletişimin hızının saliselere inmesi ve geleneksel medyanın temel işlevlerine birde "işbirliği" kavramının eklenmesiyle karşımıza yeni bir medya çıktı: Sosyal medya (Peltekoğlu, 2012: 4). Sosyal medya bireysel ve toplumsal yaşamda yoğun şekilde yer edinirken zamanla daha fazla ve karmaşı bir biçim alarak popülaritesini artırmışır. Aynı zamanda sosyal medyanın ağırlığını her geçen gün artırmasında bireylerin psiko-sosyal ihtiyaçlarını da karşılayan bir mecra olması önemli bir etkendir (Babacan, 2019: 210).

Sosyal ağ uygulamalarının öncüleri olan gençler arasında benliğin sunumu önemli bir yere sahiptir (Livingstone, 2016: 86). Sosyal medya ortamındaki arkadaşlık ilişkileri ile gerçek ortamdaki arkadaşlık ilişkileri nitelik yönünden oldukça farklıdır. Gerçek ortamlarda kurulan ve yürütülen arkadaşlık ilişkileri bir mahremiyet sınırına sahipken, sosyal medyadaki arkadaşlık ilişkilerinin mahremiyet sınırı oldukça geniştir. Yani sosyal medyada yüzlerce arkadaşa sahip olunabilirken bu ortamda kurulan ilişkiler ve yapılan paylaşımlar en yakın akrabalardan (ebeveynlerden) başlayarak uzak tanıdıklara kadar herkesin bir arada olduğu ve görebildiği bir düzlemde gerçekleşmektedir. 
2019 itibarıyla dünyada yaklaşık üç buçuk milyar insan sosyal medyayı kullanmaktadır ve bunların da \%98'i sosyal medyaya mobil cihazlar üzerinden bağlanmaktadırlar (BTIK, 2019). Sosyal medyanın geniş kitleler tarafından kabul görmesindeki en önemli faktörlerden birisi geleneksel medyanın tek yönlü buyurgan niteliğini kırması ve çift yönlü etkileşime olanak tanımasıdır. Böylece daha geniş özgürlük alanı sağlayan sosyal medya sayesinde bireyler özellikle geleneksel medya araçlarının birer propaganda alıcısı olma durumundan da kendilerini kurtarmışlardır (Ünür, 2016: 154).

Sosyal medya ortamının kullanım pratiği ve doğası gereği, bu ortamda kurulan ilişkiler uzun süreli bir bağlamdan yoksun gerçekleşmektedir. Gerçek hayatta arkadaşlık ilişkileri daha çok sabır, tahammül, fedakarlık, empati gibi duygusal bir zeminde uzun sürede kurulurken, tam tersine sosyal medyada hızlı ve kompleks biçimde kurulmaktadır (Babacan, 2017: 163). Sosyal medya bireylere özgür olduğu hissini verirken öte yandan birey gözetlendiğini düşünmeksizin bu yanılsamayla istediğini yapabilmektedir (Karaboğa, 2018: 932).

\section{Yöntem}

Araştırmada nicel veri toplama tekniği olarak anket kullanılmıştır. Tarama araştırmalarında yanıtlayıcılara tek seferde pek çok şey hakkında sorular sorularak değişkenler ölçülür ve tek bir taramada birçok hipotez test edilir (Neuman, 2016: 395). Araştırmanın evreni Sinop kent merkezinde öğrenim gören lise ve üniversite öğrencileridir. Her iki öğrenim türüne ait evrenin genel toplamı (üniversite öğrencisi 3556, lise öğrencisi 5940 (Sinop Valiliği, 2019) olmak üzere) yaklaşık 10 bin öğrencidir. Bu sayıdaki evrenden seçilen örneklem sayısı \%95 güven ve +/- 5 hata payıyla 370'dir (Bilici, 2019: 61). Ancak araştırmada hata payını düşürmek ve güven düzeyini yükseltmek amaciyla örneklem sayısı 700 olarak belirlenmiştir. Uygulamadan sonra hatalı anket formlarının elenmesiyle 611 form değerlendirmeye alınmıştır. Örneklem sayıları (n) belirlenirken, Sinop Üniversitesi'nin merkez kampüsündeki fakülte ve yüksekokullar ile kent merkezindeki ortaöğretim kurumlarının her bir türünde öğrenim gören genel öğrenci yoğunluğu ve cinsiyet dağılımı göz özününe alınmış ve orantısız tabakalı örnekleme (her tabakadan farklı oranlarda örnek) yöntemi kullanılmıştır. Araştırma 2018-2019 eğitim öğretim yılında ilgili kurumlardan etik kurul izinleri alınarak yürütülmüştür.

Araştırmada temel olarak "medya kullanım alışkanlıkları bakımından lise ve üniversite öğrencileri arasında fark var mıdır?” sorusuna cevap aranmıştır. Buna bağlı olarak alt sorular şu şekilde oluşturulmuştur;

1. Öğrencilerin cinsiyeti ile medya kullanım süreleri arasında bir ilişki var mıdır?

2. Öğrencilerin cinsiyeti ile medya kullanım amaçları arasında bir ilişki var mıdır?

3. Öğrencilerin okul türleri ile medya kullanım süreleri arasında bir ilişki var mıdır?

4. Öğrencilerin okul türleri ile medya kullanım amaçları arasında bir ilişki var mıdır? 
Araştırmaya 339 kız, 272 erkek olmak üzere toplam 611 öğrenci katılmıştır. Bu öğrencilerin 293'ü (\% 48) lise öğrencisi ve 317'si (\% 52) üniversite öğrencisidir. Anket soruları oluşturulurken öncelikle öğrencilerin sosyo demografik özelliklerini betimleyici sorulara ardından da geleneksel ve yeni medya araçlarını kullanım tarzlarını belirleyen sorulara yer verilmiştir. Araştırma evrenini oluşturan lise ve üniversite öğrencilerinin sosyo demografik özelliklerini tanımlayan frekans ve yüzde dağılımları verilerek ilgili değişkenler arasındaki ilişkiler çapraz tablolarla gösterilmiştir. Verilerin istatistiki anlamlılık düzeyi ,05 olarak belirlenmiştir.

\section{Bulgular}

$\mathrm{Bu}$ bölümde araştırma sorularına bağlı olarak ortaya çıkan sonuçlardan, sosyodemografik içerikliler temel frekans tabloları şeklinde, değişkenler arasındaki ilişkileri ortaya koyanlar ise çapraz tablolar şeklinde gösterilmiştir.

Tablo 1: Öğrencilerin sosyo-demografik durumları

\begin{tabular}{cc|c|c}
\hline & & Sayı & Geçerli \% \\
\hline \multirow{2}{*}{ Cinsiyet } & Kız & 339 & 55,5 \\
& Erkek & 272 & 44,5 \\
\hline \multirow{2}{*}{ Okul Türü } & Lise & 293 & 48,0 \\
& Üniversite & 318 & 52,0 \\
\hline \multirow{4}{*}{ Yaş Grubu } & $15-17$ & 265 & 43,5 \\
& $18-20$ & 160 & 26,2 \\
& $21-23$ & 164 & 26,9 \\
& 24 ve üzeri & 22 & 3,5 \\
\hline \multirow{4}{*}{ Yaşadığı Yer } & Köy/Kasaba & 123 & 20,1 \\
& İlçe & 172 & 28,1 \\
& il/Büyükşehir & 313 & 51,1 \\
& Yurt dışı & 4 & 0,7 \\
\hline \multirow{3}{*}{ Ortalama Aile } & 0-1000 TL. & 34 & 5,7 \\
Geliri (aylık) & 1001-2000 TL. & 117 & 19,6 \\
& 2001-3500 TL. & 179 & 29,9 \\
& 3501-5000 TL. & 145 & 24,2 \\
& 5001-7000 TL. & 83 & 13,9 \\
& 7001 TL. ve üzeri & 40 & 6,7 \\
\hline & Toplam & $\mathbf{6 1 1}$ & $\mathbf{1 0 0 , 0}$ \\
\hline
\end{tabular}

Araştırmaya 339’u kız öğrenci (\%55,5), 272'si de erkek öğrenci $(\% 44,5)$ olmak üzere toplam 611 öğrenci katılmıştır. Bunların 293’ü (\%48) Lise öğrenimi görenlerden, 317’si (\%52) ise Üniversite öğrenimi görenlerden oluşmaktadır. Öğrencilerin yaş grubu incelendiğinde; 15-17 yaş grubunun $\% 43,5 ; 18-20$ yaş grubunun $\% 26,2 ; 21-23$ yaş grubunun $\% 26,9 ; 24$ yaş ve üzerinin \%3,5 olduğu görülmektedir. Yaş grubu dağılımının örneklem dağılımına da uygun olduğu görülmektedir. Öğrencilerin yaşamlarının çoğunu geçirdikleri yer açısından; \%48,2'si 
(köy/kasaba/ilçe olarak) kırsal bölge; \%51,8’i ise il/büyükşehir dağılımı göstermektedir. Kırsal ve kentsel bölge açısından dengeli bir dağılım gösterdiği söylenebilir. Öğrencilerin ailelerinin aylık ortalama gelir durumları açısından, \%29,9'unun 2001-3500 TL.; \%24,2'sinin 3501-5000 TL.; \%19,6'sının 1001-2000 TL.; \%13,9'unun 5001-7000 TL.; \%6,7'sinin 7001 TL. ve üzerinde; \%5,7'sinin ise 0-1000 TL. arasında ortalama gelire sahip oldukları tespit edilmiştir. Öğrencilerin ailelerinin büyük çoğunluğunun alt ve orta gelir grubunda yer aldıkları söylenebilir. Anket formunda aile geliri seçenekleri belirlenirken 2019 itibarıyla, güncel asgari ücret 2000 TL. olarak kabul edilmiştir.

Tablo 2: Araştırma kapsamında yer alan okul türleri

\begin{tabular}{lcc|lcc}
\hline \multicolumn{1}{c}{ Lise } & Sayı & \% & \multicolumn{1}{c}{ Üniversite } & Sayı & \% \\
\hline Anadolu Lisesi & 78 & 12,8 & Fen-Edebiyat Fakültesi & 93 & 15,2 \\
Fen Lisesi & 51 & 8,3 & Eğitim Fakültesi & 84 & 13,7 \\
Güzel Sanatlar Lisesi & 21 & 3,4 & İlahiyat Fakültesi & 92 & 15,1 \\
Spor Lisesi & 22 & 3,6 & Sağlık Yüksekokulu & 48 & 7,9 \\
Imam Hatip Lisesi & 50 & 8,2 & & & \\
Meslek Lisesi & 72 & 11,8 & & & \\
\hline Toplam (Lise) & 294 & 48,1 & Toplam (Üniversite) & 317 & 51,9 \\
\hline Genel Toplam & \multicolumn{7}{c}{} & & $\mathbf{6 1 1}$ & $\mathbf{1 0 0 , 0}$ \\
\hline
\end{tabular}

Araştırma kapsamında yer alan okul türleri incelendiğinde; Ortaöğretim kurumlarının (Lise) oranı \%48,1; Üniversite bünyesindeki fakülte/yüksekokulların oranı ise \%51,9 dur. Örneklem sayıları belirlenirken öğrenim gördükleri okul türlerinin oranına paralel olarak hesaplanmıştır. Buna göre lise öğrencileri arasında \%12,8 Anadolu Lisesi, \%11,8 Meslek Lisesi, \%8,3 Fen Lisesi öğrencisi, \%8,2 İmam Hatip Lisesi, \%3,6 Spor Lisesi, \%3,4 Güzel Sanatlar Lisesi öğrencileri temsil edilmektedir. Üniversite öğrencilerinin örneklemi ise \%15,2 Fen-Edebiyat Fakültesi, \%15,1 İlahiyat Fakültesi, \%13,7 Eğitim Fakültesi ve \%7,9 Sağlık Yüksek Okulu öğrencilerinden oluşmaktadır.

Tablo 3: Öğrencilerin en çok izledikleri televizyon programları

\begin{tabular}{lccc}
\hline & Sayı & \% & Geçerli \% \\
\hline Eğlence/ Magazin/ Yarışma & 55 & 9,0 & 9,6 \\
Dizi/Film & 288 & 47,1 & 50,3 \\
Haber/Belgesel/Tartışma & 99 & 16,2 & 17,3 \\
Dini içerikli programlar & 16 & 2,6 & 2,8 \\
Spor programları & 35 & 5,7 & 6,1 \\
İlgimi çeken her program & 78 & 12,8 & 13,6 \\
Diğer & 2 & 0,3 & 0,3 \\
\hline Toplam & 573 & 93,8 & 100,0 \\
Kayıp & 38 & 6,2 & \\
Toplam & 611 & 100,0 & \\
\hline
\end{tabular}

Öğrencilerin geneli tarafından en çok izlenen televizyon programları incelendiğinde; \%50,3'ünün “dizi/film”; \%17,3'ünün "haber/belgesel/tartışma” programı izledikleri görülürken, \%13,6'sı ise "ilgimi çeken her programı izlerim” şeklinde cevaplamıştır. Televizyonun genellikle boş zaman değerlendirmeye yönelik bir araç olduğu söylenebilir. 
Lise ve Üniversite Öğrencilerinin Medya Araçları Kullanımlarının

Tablo 4: Öğrencilerin internet kullanma amac1

\begin{tabular}{lccc}
\hline & Sayı & \% & Geçerli \% \\
\hline Haber / e posta & 43 & 7,0 & 7,1 \\
Dizi ya da film izlemek & 59 & 9,7 & 9,7 \\
Sosyal ağlara bağlanmak & 377 & 61,7 & 62,2 \\
Araştırma/Bilgi edinmek & 57 & 9,3 & 9,4 \\
Eğlence/ Alışveriş & 66 & 10,8 & 10,9 \\
Diğer & 4 & 0,7 & 0,7 \\
\hline Toplam & 606 & 99,2 & 100,0 \\
Kayıp & 5 & 0,8 & \\
Toplam & 611 & 100,0 & \\
\hline
\end{tabular}

Öğrencilerin internet kullanma amaçları genel olarak incelendiğinde; \%62,2’lik büyük çoğunluğunun "sosyal ağlara bağlanmak" amaçlı kullandıkları görülmektedir. \%10,9'u eğlenmek ya da alışveriş yapmak amaçlı kullanırken; \%9,7'si ise “dizi ya da film” izlemek amaçlı internet kullanmaktadırlar.

Tablo 5: Öğrencilerin sosyal medya kullanım sıklığı

\begin{tabular}{lccc}
\hline & Sayı & \% & Geçerli \% \\
\hline Günlük 1 saatten az & 124 & 20,3 & 20,5 \\
Günlük 1-2 saat & 219 & 35,8 & 36,3 \\
Günlük 3-4 saat & 107 & 17,5 & 17,7 \\
Günlük 5 saat ve üzeri & 103 & 16,9 & 17,1 \\
Haftada birkaç gün & 27 & 4,4 & 4,5 \\
Hiç kullanmam & 23 & 3,8 & 3,8 \\
Diğer & 1 & 0,2 & 0,2 \\
\hline Toplam & 604 & 98,9 & 100,0 \\
Kayıp & 7 & 1,1 & \\
Toplam & 611 & 100,0 & \\
\hline
\end{tabular}

Öğrencilerin sosyal medya kullanım sıklı̆̆ incelendiğinde; \%36,3'ünün "günde 1-2 saat”, \%20,5'inin günde 1 saatten az kullandıkları görülürken, \%17,7'sinin günde 3-4 saat, $\% 17,1$ 'ini ise günde 5 saat ve üzerinde sosyal medya kullandıkları anlaşılmıştır. Sosyal medya kullanmayanların oranı \%3,8 dir. Bu anlamda öğrencilerin \%91,5'i sosyal medyayı her gün kullanmaktadırlar.

Tablo 6: Öğrencilerin sosyal medya kullanma amaçları

\begin{tabular}{lccc}
\hline & Sayı & \% & Geçerli \% \\
\hline Güncel olayları takip etmek & 177 & 29,0 & 30,3 \\
Sohbet etmek/ Eğlence & 165 & 27,0 & 28,3 \\
Zaman geçirmek & 212 & 34,7 & 36,3 \\
Yeni arkadaşlar bulmak & 29 & 4,7 & 5,0 \\
Diğer & 1 & 0,2 & 0,2 \\
\hline Toplam & 584 & 95,6 & 100,0 \\
Kayıp & 27 & 4,4 & \\
Toplam & 611 & 100,0 & \\
\hline
\end{tabular}

Öğrencilerin sosyal medya kullanım amaçları incelendiğinde; \%36,3'ünün "zaman geçirmek”, \%30,3'ünün "güncel olayları takip etmek", \%28,3'ünün "sohbet etmek/ eğlence" amaçl1, \%5'inin ise "yeni arkadaşlar bulmak" şeklinde cevap verdikleri görülmektedir. Gençlerin 
günlük olayları televizyon ya da gazetelerden takip etmek yerine internet tabanlı sosyal medyaya yöneldikleri söylenebilir.

Tablo 7: Öğrencilerin en çok kullandıkları sosyal mecra

\begin{tabular}{lccc}
\hline & Sayı & \% & Geçerli \% \\
\hline Facebook & 34 & 5,6 & 6,0 \\
Twetter & 22 & 3,6 & 3,9 \\
Instagram & 380 & 62,2 & 66,5 \\
Whatsapp & 94 & 15,4 & 16,5 \\
Youtube & 33 & 5,4 & 5,8 \\
Diğer & 8 & 1,3 & 1,4 \\
\hline Toplam & 571 & 93,5 & 100,0 \\
Kayıp & 40 & 6,5 & \\
Toplam & 611 & 100,0 & \\
\hline
\end{tabular}

Öğrencilerin sosyal medyada en çok kullandıkları mecra incelendiğinde; \%66,5'inin İnstagram, \%16,5'inin Whatsapp, \%6'sının Facebook, \%5,8'inin Youtube ve \%3,9'unun ise Twetter kullandıkları görülmektedir.

Tablo 8: Öğrencilerin internete ilişkin değerlendirmeleri

\begin{tabular}{|c|c|c|c|c|c|c|}
\hline \multicolumn{2}{|l|}{ İnternet } & $\begin{array}{c}\text { Her } \\
\text { zaman }\end{array}$ & $\begin{array}{c}\text { Çoğu } \\
\text { zaman }\end{array}$ & $\begin{array}{l}\text { Ara } \\
\text { sira }\end{array}$ & $\begin{array}{c}\text { Çok } \\
\text { nadir }\end{array}$ & $\begin{array}{l}\text { Hiçbir } \\
\text { zaman }\end{array}$ \\
\hline \multirow{2}{*}{ Boş zamanlarda internete girerim } & Say1 & 146 & 283 & 153 & 19 & 10 \\
\hline & $\%$ & $\% 23,9$ & $\% 46,3$ & $\% 25$ & $\% 3,1$ & $\% 1,6$ \\
\hline \multirow{2}{*}{ İnternete girdiğim zaman keyif alırım } & Say1 & 154 & 253 & 155 & 38 & 11 \\
\hline & $\%$ & $\% 25,2$ & $\% 41,4$ & $\% 25,4$ & $\% 6,2$ & $\% 1,8$ \\
\hline \multirow{2}{*}{ Cep telefonumdan internete girerim } & Say1 & 308 & 240 & 49 & 7 & 7 \\
\hline & $\%$ & $\% 50,4$ & $\% 39,3$ & $\% 8,0$ & $\% 1,1$ & $\% 1,1$ \\
\hline \multirow{2}{*}{ İnterneti faydalı bulurum } & Say1 & 159 & 241 & 173 & 27 & 11 \\
\hline & $\%$ & $\% 26$ & $\% 39,4$ & $\% 28,3$ & $\% 4,4$ & $\% 1,8$ \\
\hline \multirow{2}{*}{ Gündemi internetten takip ederim } & Say1 & 201 & 244 & 109 & 36 & 21 \\
\hline & $\%$ & $\% 32,9$ & $\% 39,9$ & $\% 17,8$ & $\% 5,9$ & $\% 3,4$ \\
\hline
\end{tabular}

Öğrencilerin internete ilişkin genel değerlendirmeleri incelendiğinde; “Boş zamanlarda internete girme" oranlarında \%46,3'ünün çoğu zaman, \%25'inin ara sıra, \%23,9'unun her zaman, \%3,1'inin nadiren internete girdiği görülürken, \%1,6'sının ise hiçbir zaman internete girmediği görülmektedir. "İnternetten keyif alma" durumlarında; \%41,4'ü çoğu zaman, \%25,4'ünün ara sıra, \%25,2'sinin her zaman, \%6,2'sinin nadiren keyif aldığı, buna karşın \%1,8'inin ise hiçbir zaman keyif almadığ 1 görülmektedir. “Cep telefonundan internete bağlanabilme” durumlarında; \%50,4'ünün her zaman, \%39,3'ünün çoğu zaman, \%8'inin ara sıra, \%1,1'inin nadiren cep telefonunda internete bağlandığı görülürken, \%1,1'inin ise hiçbir zaman cep telefonundan internete bağlanmadığı görülmektedir. Babacan'ın (2017) araştırmasında da üniversite öğrencilerinin \%47,2'sinin cep telefonlarından internete girmeleri araştırmamızla büyük benzerlik taşımaktadır. "İnterneti faydalı bulma" durumları incelendiğinde; \%39,4'ü çoğu zaman, \%28,3'ü ara sira, \%26'sı her zaman, \%4,4'ü ise nadiren faydalı bulduğunu belirtirken, \%1,8'i hiçbir zaman faydalı bulmadı̆̆ını belirtmiştir. "Gündemi internetten takip etme" durumları 
incelendiğinde; \%39,9'u “çoğu zaman”, \%\%32,9'u “her zaman”, \%17,8'i ara sıra, \%5,9'u nadiren gündemi internetten takip ederken, $\% 3,4$ 'ü ise gündemi internetten takip etmediklerini belirtmişlerdir. Buna göre öğrenciler boş vakitlerini genellikle internete girerek değerlendirmekte ve çoğunluğu internete cep telefonlarından girmektedir. İnternete girmek onlar için keyifli ve faydalı bir faaliyet olarak algılanmakta, gündemi de yine internet üzerinden takip etmektedirler.

Tablo 9: Öğrencilerin televizyona ilişkin değerlendirmeleri

\begin{tabular}{|c|c|c|c|c|c|c|}
\hline \multicolumn{2}{|l|}{ Televizyon } & $\begin{array}{c}\text { Her } \\
\text { zaman }\end{array}$ & $\begin{array}{c}\text { Çoğu } \\
\text { zaman }\end{array}$ & $\begin{array}{l}\text { Ara } \\
\text { sira }\end{array}$ & $\begin{array}{c}\text { Çok } \\
\text { nadir }\end{array}$ & $\begin{array}{l}\text { Hiçbir } \\
\text { zaman }\end{array}$ \\
\hline \multirow{2}{*}{$\begin{array}{l}\text { Sadece zaman geçirmek için televizyon } \\
\text { izlerim }\end{array}$} & Say1 & 45 & 126 & 176 & 169 & 95 \\
\hline & $\%$ & $\% 7,4$ & $\% 20,6$ & $\% 28,8$ & $\% 27,7$ & $\% 15,5$ \\
\hline \multirow{2}{*}{ Televizyon izlemekten keyif alırım } & Say1 & 55 & 122 & 228 & 140 & 66 \\
\hline & $\%$ & $\% 9,0$ & $\% 20,0$ & $\% 37,3$ & $\% 22,9$ & $\% 10,8$ \\
\hline \multirow{2}{*}{$\begin{array}{l}\text { Televizyonda istediğim programı } \\
\text { bulabilirim }\end{array}$} & Say1 & 34 & 56 & 195 & 230 & 95 \\
\hline & $\%$ & $\% 5,6$ & $\% 9,2$ & $\% 32,0$ & $\% 37,7$ & $\% 15,6$ \\
\hline \multirow{2}{*}{ Televizyonu faydalı bulurum } & Say1 & 28 & 90 & 237 & 171 & 85 \\
\hline & $\%$ & $\% 4,6$ & $\% 14,7$ & $\% 38,8$ & $\% 28,0$ & $\% 13,9$ \\
\hline \multirow{2}{*}{ Gündemi televizyondan takip ederim } & Say1 & 36 & 83 & 223 & 196 & 73 \\
\hline & $\%$ & $\% 5,9$ & $\% 13,6$ & $\% 36,5$ & $\% 32,1$ & $\% 11,9$ \\
\hline
\end{tabular}

Öğrencilerin televizyona ilişkin değerlendirmeleri incelendiğinde; "Sadece zaman geçirmek için televizyon izleyenlerin", \%28,8'i ara sıra, \%27,7'si nadiren, \%20,6's1 çoğu zaman, \%7,4'ü her zaman cevabı verirken \%15,5'i hiçbir zaman, zaman geçirmek için televizyon izlemediğini belirtmiştir. Buna göre öğrenciler arasında televizyon, internet kadar yaygın bir zaman geçirme aracı olarak kullanılmamaktadır. "Televizyon izlemekten keyif alma" durumları incelendiğinde; öğrencilerin \%37,3’ü ara sıra, \%22,9'u nadiren, \%20'si çoğu zaman, \%9'u her zaman keyif aldığını belirtirken, \%10,8'i hiçbir zaman keyif almadığını belirtmiştir. Buna göre televizyon, öğrenciler arasında internet kadar keyifli görünmemektedir. "Televizyonda her istediği programı bulabilme" durumları incelendiğinde; öğrencilerin \%37,7'si nadiren, \%32'si ara sıra, \%9,2'si “çoğu zaman”, \%5,6's1 "her zaman” cevabı verirken \%15,6'sı hiçbir zaman cevabını vermişlerdir. "Televizyonu faydalı bulma" durumları incelendiğinde; \%38,8'i ara sıra, \%28'i nadiren, \%14,7'si “çoğu zaman”, \%4,6's1 "her zaman” faydalı bulurken, \%13,9'u hiçbir zaman faydalı bulmamaktadır. Öğrenciler arasında genel kanı televizyonun faydalı bir araç olmadığı yönündedir. "Gündemi televizyondan takip etme" durumları incelendiğinde; \%36,5'i ara sıra, \%32,1'i nadiren, \%13,6'sı çoğu zaman, \%5,9'u her zaman cevab1 verirken, \%11,9'u hiçbir zaman gündemi internetten takip etmediklerini belirtmişlerdir. Öğrenciler arasında gündemi televizyondan takip etme durumu düşüktür. Tablo 8 'den de anlaşılacağı üzere gündemi internetten takip etmektedirler. 
Tablo 10: Öğrencilerin gazete okumaya ilişkin değerlendirmeleri

\begin{tabular}{|c|c|c|c|c|c|c|}
\hline \multicolumn{2}{|l|}{ Gazete } & $\begin{array}{c}\text { Her } \\
\text { zaman }\end{array}$ & $\begin{array}{c}\text { Çoğu } \\
\text { zaman }\end{array}$ & $\begin{array}{l}\text { Ara } \\
\text { sira }\end{array}$ & $\begin{array}{c}\text { Çok } \\
\text { nadir }\end{array}$ & $\begin{array}{l}\text { Hiçbir } \\
\text { zaman }\end{array}$ \\
\hline \multirow{2}{*}{ Basılı gazete okurum } & Say1 & 18 & 36 & 165 & 220 & 172 \\
\hline & $\%$ & $\% 2,9$ & $\% 5,9$ & $\% 27$ & $\% 36$ & $\% 28,2$ \\
\hline \multirow{2}{*}{ Gazeteleri internetten takip ederim } & Say1 & 66 & 144 & 133 & 128 & 140 \\
\hline & $\%$ & $\% 10,8$ & $\% 23,6$ & $\% 21,8$ & $\% 20,9$ & $\% 22,9$ \\
\hline
\end{tabular}

Öğrencilerin gazete okumaya ilişkin görüşleri incelendiğinde; "Basıl gazete okuma" oranlarında \%36'sı nadiren, , \%27'si ara sıra, \%5,9'u “çoğu zaman”, \%2,9'u "her zaman" basılı gazete okurken, \%28,2'si hiçbir zaman basılı gazete okumadığını belirtmiştir. "Gazeteleri internetten takip etme" durumlarında ise; \%23,6'sı çoğu zaman, \%21,8'i ara sıra, \%209'u nadiren ve $\% 10,8$ ' her zaman internetten takip ederken, \%22,9'u hiçbir zaman cevabını vermiştir. Bu sonuçlara göre öğrencilerin basılı gazete okuma alışkanlığı olmadığı hatta internet üzerinden bile gazete okuma alışkanlığına sahip olmadıkları belirtilebilir.

Tablo 11: Öğrencilerin cinsiyet ve okul değişkenine göre en çok izledikleri televizyon programı türleri

\begin{tabular}{|c|c|c|c|c|c|c|c|}
\hline \multirow{2}{*}{\multicolumn{2}{|c|}{$\begin{array}{l}\text { En Çok İzlenen } \\
\text { Televizyon Program } \\
\text { Türleri } \\
\end{array}$}} & \multicolumn{2}{|c|}{ Cinsiyet } & \multirow[b]{2}{*}{ Toplam } & \multicolumn{2}{|c|}{ Okul Türü } & \multirow[b]{2}{*}{ Toplam } \\
\hline & & $\mathrm{K} 1 \mathrm{Z}$ & Erkek & & Lise & Üniversite & \\
\hline \multirow{3}{*}{$\begin{array}{l}\text { Eğlence/ } \\
\text { Magazin/ } \\
\text { Yarışma }\end{array}$} & Say1 & 38 & 17 & 55 & 27 & 28 & 55 \\
\hline & Satır & $\% 69,1$ & $\% 30,9$ & $\% 100$ & $\% 49,1$ & $\% 50,9$ & $\% 100$ \\
\hline & Sütun & $\% 11,8$ & $\% 6,7$ & $\% 9,6$ & $\% 10$ & $\% 9,3$ & $\% 9,6$ \\
\hline \multirow{3}{*}{ Dizi/ Film } & Say1 & 176 & 112 & 288 & 150 & 138 & 288 \\
\hline & Satır & $\% 61,1$ & $\% 38,9$ & $\% 100$ & $\% 52,1$ & $\% 47,9$ & $\% 100$ \\
\hline & Sütun & $\% 54,8$ & $\% 44,4$ & $\% 50,3$ & $\% 55,4$ & $\% 45,7$ & $\% 50,3$ \\
\hline \multirow{3}{*}{$\begin{array}{l}\text { Haber/ } \\
\text { Belgesel/ } \\
\text { Tartışma }\end{array}$} & Say1 & 46 & 53 & 99 & 40 & 59 & 99 \\
\hline & Satır & $\% 46,5$ & $\% 53,5$ & $\% 100$ & $\% 40,4$ & $\% 59,6$ & $\% 100$ \\
\hline & Sütun & $\% 14,3$ & $\% 21$ & $\% 17,3$ & $\% 14,8$ & $\% 19,5$ & $\% 17,3$ \\
\hline \multirow{3}{*}{$\begin{array}{l}\text { İlgimi çeken } \\
\text { her program }\end{array}$} & Say1 & 48 & 30 & 78 & 34 & 46 & 80 \\
\hline & Satır & $\% 61,5$ & $\% 38,5$ & $\% 100$ & $\% 42,5$ & $\% 57,5$ & $\% 100$ \\
\hline & Sütun & $\% 15$ & $\% 11,9$ & $\% 13,6$ & $\% 12,5$ & $\% 15,2$ & $\% 14,0$ \\
\hline \multirow{3}{*}{$\begin{array}{l}\text { Dini içerikli } \\
\text { programlar }\end{array}$} & Say1 & 7 & 9 & 16 & 3 & 13 & 16 \\
\hline & Satır & $\% 43,8$ & $\% 56,3$ & $\% 100$ & $\% 18,8$ & $\% 81,3$ & $\% 100$ \\
\hline & Sütun & $\% 2,2$ & $\% 3,6$ & $\% 2,8$ & $\% 1,1$ & $\% 4,3$ & $\% 2,8$ \\
\hline \multirow{3}{*}{$\begin{array}{l}\text { Spor } \\
\text { programları }\end{array}$} & Say1 & 6 & 29 & 35 & 17 & 18 & 35 \\
\hline & Satır & $\% 17,1$ & $\% 82,9$ & $\% 100$ & $\% 48,6$ & $\% 51,4$ & $\% 100$ \\
\hline & Sütun & $\% 1,9$ & $\% 11,5$ & $\% 6,1$ & $\% 6,3$ & $\% 6$ & $\% 6,1$ \\
\hline \multirow{3}{*}{ Diğer } & Say1 & 0 & 2 & 2 & 0 & 0 & 0 \\
\hline & Satır & $\% 0,0$ & $\% 100$ & $\% 100$ & $\% 0,0$ & $\% 100$ & $\% 100$ \\
\hline & Sütun & $\% 0,0$ & $\% 0,8$ & $\% 0,3$ & $\% 0,0$ & $\% 0,0$ & $\% 0,0$ \\
\hline \multirow{3}{*}{ Toplam } & Say1 & 321 & 252 & 573 & 271 & 302 & 573 \\
\hline & Satır & $\% 56,0$ & $\% 44,0$ & $\% 100$ & $\% 47,3$ & $\% 52,7$ & $\% 100$ \\
\hline & Sütun & $\% 100$ & $\% 100$ & $\% 100$ & $\% 100$ & $\% 100$ & $\% 100$ \\
\hline 36,473 & \multicolumn{2}{|c|}{$\mathrm{df}=6$} & \multicolumn{2}{|c|}{$\mathrm{P}=0,000$} & \multicolumn{3}{|c|}{$x^{2}=10,59 \mathrm{df}=5 \mathrm{P}=0,060(\mathrm{P}>0,05)$} \\
\hline
\end{tabular}

Cinsiyete göre en çok tercih edilen televizyon programları incelendiğinde istatistiki yönden anlamlı olduğu $(\mathrm{P}=0,000 . \mathrm{P}<0,05)$ görülmüştür. Her iki cinsiyette de (k1zlarda \%54,8, 
erkeklerde \%44,4) en çok dizi/film/müzik programları tercih edilirken; eğlence/ magazin/yarışma programlarının izlenme oranı kız öğrencilerde \%69,1, erkek öğrencilerde \%30,9; Dizi/Film/Müzik programları kı öğrencilerde $\% 61,1$; erkek öğrencilerde $\% 38,9$; Haber/Belgesel/Tartışma programları kız öğrenciler arasında \%46,5, erkek öğrenciler arasında \%53,5; İlgimi çeken her programı izlerim diyenlerin oranı kız öğrenciler arasında \%61,5, erkek öğrenciler arasında \%38,5; dini programların izlenme oranı ise kız öğrencilerde \%43,8, erkek öğrencilerde \%56,3 dür. Yine spor programlarının izlenme oranında erkek öğrencilerin oranı $(\% 82,9)$ yüksektir. Buna göre kız öğrenciler ağırlıklı olarak "eğlence/magazin/ yarışma" ve "dizi/film/müzik" programlarını tercih ederken; erkek öğrenciler ise haber/belgesel/tartı̧̧ma, dini programlar ve spor programlarını tercih etmektedirler.

Tablo 12: Öğrencilerin cinsiyet ve okul değişkenine göre televizyon izleme durumları

\begin{tabular}{|c|c|c|c|c|c|c|c|}
\hline \multirow{2}{*}{\multicolumn{2}{|c|}{$\begin{array}{c}\begin{array}{c}\text { Televizyon İzleme } \\
\text { Sıklığı }\end{array} \\
\end{array}$}} & \multicolumn{2}{|c|}{ Cinsiyet } & \multirow{2}{*}{ Toplam } & \multicolumn{2}{|c|}{ Okul Türü } & \multirow[t]{2}{*}{ Toplam } \\
\hline & & $\mathrm{K}_{1 \mathrm{Z}}$ & Erkek & & Lise & Üniversite & \\
\hline \multirow{3}{*}{$\begin{array}{l}\text { Günde } \\
1 \text { saatten az }\end{array}$} & Say1 & 76 & 52 & 128 & 50 & 78 & 128 \\
\hline & Satır & $\% 59,4$ & $\% 40,6$ & $\% 100$ & $\% 39,1$ & $\% 60,9$ & $\% 100$ \\
\hline & Sütun & $\% 22,5$ & $\% 19,1$ & $\% 21$ & $\% 17,1$ & $\% 24,5$ & $\% 21,0$ \\
\hline \multirow{3}{*}{$\begin{array}{l}\text { Günde } \\
1-2 \text { saat }\end{array}$} & Say1 & 83 & 80 & 163 & 86 & 77 & 163 \\
\hline & Satır & $\% 50,9$ & $\% 49,1$ & $\% 100$ & $\% 52,8$ & $\% 47,2$ & $\% 100$ \\
\hline & Sütun & $\% 24,6$ & $\% 29,4$ & $\% 26,7$ & $\% 29,5$ & $\% 24,2$ & $\% 26,7$ \\
\hline \multirow{3}{*}{$\begin{array}{l}\text { Günde } \\
\text { 3-4 saat }\end{array}$} & Say1 & 23 & 26 & 49 & 29 & 20 & 49 \\
\hline & Satır & $\% 46,9$ & $\% 53,1$ & $\% 100$ & $\% 59,2$ & $\% 40,8$ & $\% 100$ \\
\hline & Sütun & $\% 6,8$ & $\% 9,6$ & $\% 8$ & $\% 9,9$ & $\% 6,3$ & $\% 8$ \\
\hline \multirow{3}{*}{$\begin{array}{l}\text { Günde } \\
5 \text { saat ve üstü }\end{array}$} & Say1 & 2 & 8 & 10 & 5 & 5 & 10 \\
\hline & Satır & $\% 20$ & $\% 80$ & $\% 100$ & $\% 50$ & $\% 50$ & $\% 100$ \\
\hline & Sütun & $\% 0,6$ & $\% 2,9$ & $\% 1,6$ & $\% 1,7$ & $\% 1,6$ & $\% 1,6$ \\
\hline \multirow{3}{*}{$\begin{array}{l}\text { Haftada } \\
\text { birkaç gün }\end{array}$} & Say1 & 130 & 76 & 206 & 88 & 118 & 206 \\
\hline & Satır & $\% 63,1$ & $\% 36,9$ & $\% 100$ & $\% 42,7$ & $\% 57,3$ & $\% 100$ \\
\hline & Sütun & $\% 38,5$ & $\% 27,9$ & $\% 33,8$ & $\% 30,1$ & $\% 37,1$ & $\% 33,8$ \\
\hline \multirow{3}{*}{ Hiç izlemem } & Say1 & 23 & 28 & 51 & 31 & 20 & 51 \\
\hline & Satır & $\% 45,1$ & $\% 54,9$ & $\% 100$ & $\% 60,8$ & $\% 39,2$ & $\% 100$ \\
\hline & Sütun & $\% 6,8$ & $\% 10,3$ & $\% 8,4$ & $\% 10,6$ & $\% 6,3$ & $\% 8,4$ \\
\hline \multirow{3}{*}{ Diğer } & Say1 & 1 & 2 & 3 & 3 & 0 & 3 \\
\hline & Satır & $\% 33,3$ & $\% 66,7$ & $\% 100$ & $\% 100$ & $\% 0,0$ & $\% 100$ \\
\hline & Sütun & $\% 0,3$ & $\% 0,7$ & $\% 0,5$ & $\% 1,0$ & $\% 0,0$ & $\% 0,5$ \\
\hline \multirow{4}{*}{ Toplam } & Say1 & 338 & 272 & 610 & 292 & 318 & 610 \\
\hline & Satır & $\% 55,4$ & $\% 44,6$ & $\% 100$ & $\% 47,9$ & $\% 52,1$ & $\% 100$ \\
\hline & Sütun & $\% 100$ & $\% 100$ & $\% 100$ & $\% 100$ & $\% 100$ & $\% 100$ \\
\hline & \multicolumn{2}{|c|}{$\begin{array}{c}x^{2}=16,368 \\
\mathrm{P}=0, \mathbf{0 1 2}\end{array}$} & \multicolumn{2}{|c|}{$\begin{array}{c}\mathrm{df}=6 \\
(\mathrm{P}<0,05)\end{array}$} & \multicolumn{2}{|c|}{$\begin{array}{c}x^{2}=16,939 \\
\mathrm{P}=0, \mathbf{0 1 0}\end{array}$} & $\begin{array}{l}=6 \\
<0,05)\end{array}$ \\
\hline
\end{tabular}

Öğrencilerin televizyon izleme sıklıkları incelendiğinde; \%33,8'inin (206 kişi) haftada birkaç gün, \%26,7'sinin (163 kişi) günde 1-2 saat, \%21'inin (128 kişi) günde 1 saatten az, \%8'inin ise günde 3-4 saat izledikleri görülürken, hiç izlemeyenlerin oranı \%8,4 dür. 
Öğrencilerin televizyon izleme durumları, $\underline{\text { cinsiyet }}$ değişkenine göre incelendiğinde; günde 1 saatten az izleyenlerde kız öğrenciler \%59,4, erkek öğrenciler \%40,6; günde 1-2 saat izleyenlerde kız öğrenciler \%50,9, erkek öğrenciler \%49,1; günde 3-4 saat izleyenlerde kız öğrenciler \%46,9, erkek öğrenciler \%53,1; günde 5 saat ve üstünde izleyenlerde k1z öğrenciler $\% 20$, erkek öğrenciler \%80; Haftada birkaç gün izleyenlerde k1z öğrenciler \%63,1, erkek öğrenciler \%36,9 orana sahipken, hiç televizyon izlemeyenlerde kız öğrenciler \%45,1, erkek öğrenciler $\% 54,9$ orana sahiptir.

Öğrencilerin televizyon izleme durumları, okul türü değişkenine göre incelendiğinde ise; cinsiyet değişkeninde olduğu gibi her iki öğrenim düzeyinde de çoğunluk \%33,6 (206 kişi) haftada birkaç gün televizyon izlediklerini belirtmişlerdir. Cinsiyete göre kız öğrencilerin çoğunluğu göze çarparken okul türünde üniversite öğrencilerinin çoğunluğu göze çarpmaktadır. $\mathrm{Bu}$ sonuçlara göre öğrencilerin günlük internet kullanım süreleri (\%32,6 günlük 3-4 saat), televizyon izleme sürelerinden (\%26,7 günlük 1-2 saat) yüksek bulunmuştur.

Tablo 13: Öğrencilerin cinsiyet ve okul değişkenine göre internet kullanım sıklıkları

\begin{tabular}{|c|c|c|c|c|c|c|c|}
\hline \multirow{2}{*}{\multicolumn{2}{|c|}{ İnternet Kullanım Sıklığı }} & \multicolumn{2}{|c|}{ Cinsiyet } & \multirow{2}{*}{ Toplam } & \multicolumn{2}{|c|}{ Okul Türü } & \multirow[t]{2}{*}{ Toplam } \\
\hline & & $\mathrm{K}_{1 \mathrm{Z}}$ & Erkek & & Lise & Üniversite & \\
\hline \multirow{3}{*}{$\begin{array}{l}\text { Günde } \\
1 \text { saatten az }\end{array}$} & Sayı & 24 & 23 & 47 & 32 & 15 & 47 \\
\hline & Satır & $\% 51,1$ & $\% 48,9$ & $\% 100$ & $\% 68,1$ & $\% 31,9$ & $\% 100$ \\
\hline & Sütun & $\% 7,1$ & $\% 8,5$ & $\% 7,7$ & $\% 10,9$ & $\% 4,7$ & $\% 7,7$ \\
\hline \multirow{3}{*}{$\begin{array}{l}\text { Günde } \\
1-2 \text { saat }\end{array}$} & Say1 & \multirow{3}{*}{$\begin{array}{c}90 \\
\% 46,8 \\
\% 26,5\end{array}$} & \multirow{3}{*}{$\begin{array}{c}104 \\
\% 53,2 \\
\% 38,2\end{array}$} & \multirow{3}{*}{$\begin{array}{c}194 \\
\% 100 \\
\% 31,8\end{array}$} & \multirow{3}{*}{$\begin{array}{c}111 \\
\% 57,2 \\
\% 37,9\end{array}$} & \multirow{3}{*}{$\begin{array}{c}83 \\
\% 42,8 \\
\% 26,1\end{array}$} & \multirow{3}{*}{$\begin{array}{c}194 \\
\% 100 \\
\% 31,8\end{array}$} \\
\hline & Satır & & & & & & \\
\hline & Sütun & & & & & & \\
\hline \multirow{3}{*}{$\begin{array}{l}\text { Günde } \\
\text { 3-4 saat }\end{array}$} & Say1 & \multirow{3}{*}{$\begin{array}{c}119 \\
\% 62,3 \\
\% 35,1 \\
\end{array}$} & \multirow{3}{*}{$\begin{array}{c}72 \\
\% 37,7 \\
\% 26,5\end{array}$} & \multirow{3}{*}{$\begin{array}{c}191 \\
\% 100 \\
\% 31,3\end{array}$} & \multirow{3}{*}{$\begin{array}{c}84 \\
\% 44 \\
\% 28,7\end{array}$} & \multirow{3}{*}{$\begin{array}{c}107 \\
\% 56 \\
\% 33,6\end{array}$} & \multirow{3}{*}{$\begin{array}{c}191 \\
\% 100 \\
\% 31,3\end{array}$} \\
\hline & Satır & & & & & & \\
\hline & Sütun & & & & & & \\
\hline \multirow{3}{*}{$\begin{array}{l}\text { Günde } \\
5 \text { saat ve üstü }\end{array}$} & Say1 & \multirow{3}{*}{$\begin{array}{c}91 \\
\% 61,5 \\
\% 26,8\end{array}$} & \multirow{3}{*}{$\begin{array}{c}57 \\
\% 38,5 \\
\% 21\end{array}$} & \multirow{3}{*}{$\begin{array}{c}148 \\
\% 100 \\
\% 24,2\end{array}$} & \multirow{3}{*}{$\begin{array}{c}40 \\
\% 27 \\
\% 13,7\end{array}$} & \multirow{3}{*}{$\begin{array}{c}108 \\
\% 73 \\
\% 34\end{array}$} & \multirow{3}{*}{$\begin{array}{c}148 \\
\% 100 \\
\% 24,2\end{array}$} \\
\hline & Satır & & & & & & \\
\hline & Sütun & & & & & & \\
\hline \multirow{3}{*}{$\begin{array}{l}\text { Haftada } \\
\text { birkaç gün }\end{array}$} & Say1 & \multirow{3}{*}{$\begin{array}{c}12 \\
\% 48 \\
\% 3,5\end{array}$} & \multirow{3}{*}{$\begin{array}{c}13 \\
\% 52 \\
\% 4,8\end{array}$} & \multirow{3}{*}{$\begin{array}{c}25 \\
\% 100 \\
\% 4,1\end{array}$} & \multirow{3}{*}{$\begin{array}{c}23 \\
\% 92 \\
\% 7,8\end{array}$} & 2 & 25 \\
\hline & Satır & & & & & $\% 8$ & $\% 100$ \\
\hline & Sütun & & & & & $\% 0,6$ & $\% 4,1$ \\
\hline & Say1 & 3 & 2 & 5 & 3 & 2 & 5 \\
\hline Hiç kullanmam & Satır & $\% 60$ & $\% 40$ & $\% 100$ & $\% 60$ & $\% 40$ & $\% 100$ \\
\hline & Sütun & $\% 0,9$ & $\% 0,7$ & $\% 0,8$ & $\% 1$ & $\% 0,6$ & $\% 0,8$ \\
\hline & Say1 & 0 & 1 & 1 & 0 & 1 & 1 \\
\hline Diğer & Satır & $\% 0,0$ & $\% 100$ & $\% 100$ & $\% 0,0$ & $\% 100$ & $\% 100$ \\
\hline & Sütun & $\% 0,0$ & $\% 0,4$ & $\% 0,2$ & $\% 0,0$ & $\% 0,3$ & $\% 0,2$ \\
\hline & Say1 & 339 & 272 & 611 & 293 & 318 & 611 \\
\hline Toplam & Satır & $\% 55,5$ & $\% 44,5$ & $\% 100$ & $\% 48$ & $\% 52$ & $\% 100$ \\
\hline & Sütun & $\% 100$ & $\% 100$ & $\% 100$ & $\% 100$ & $\% 100$ & $\% 100$ \\
\hline & & $\begin{array}{l}x^{2}=1 \\
\mathrm{P}=0,0\end{array}$ & & $\begin{array}{l}6 \\
0,05)\end{array}$ & $\begin{array}{l}x^{2}=62, \\
\mathrm{P}=0,00\end{array}$ & & $\begin{array}{l}\mathrm{df}=6 \\
(\mathrm{P}<0,05)\end{array}$ \\
\hline
\end{tabular}

Öğrencilerin İnternet kullanım sıklıkları incelendiğinde; \%31,8'inin "günlük 1-2 saat”, \%31,3'ünün “günlük 3-4 saat”, \%24,2'sinin “günlük 5 saat ve üstü”nde internet kullandıkları 
görülürken, günde 1 saatten az kullananların oranı \%7,7; haftada birkaç gün kullananların oranı ise $\% 4,1$ dir.

Öğrencilerin internet kullanma durumları ile "cinsiyet” değişkeni arasında anlamlı bir ilişki görülmüştür $(\mathrm{P}<0,05)$; günde 1 saatten az kullananlarda kız öğrenciler \%51,1, erkek öğrenciler \%48,9; günde 1-2 saat kullananlarda kız öğrenciler \%46,8, erkek öğrenciler \%53,2; günde 3-4 saat kullananlarda k1z öğrenciler \%61,3, erkek öğrenciler \%38,7; günde 5 saat ve üstünde kullananlarda k1z öğrenciler \%61,5, erkek öğrenciler \%38,5; Haftada birkaç gün kullananlarda kız öğrenciler \%48, erkek öğrenciler \%52 orana sahipken, hiç internet kullanmayanlarda kız öğrenciler \%60, erkek öğrenciler \%40 orana sahiptir. Cinsiyet değişkenine göre kız öğrencilerin internet kullanma süreleri erkek öğrencilerden daha fazladır.

Öğrencilerin internet kullanma durumları ile okul türü değişkeni arasında da anlamlı bir ilişki görülmüştür $(\mathrm{P}<0,05)$; Lise öğrencileri arasında çoğunluk (\%37) günde 1-2 saat kullanırken, üniversite öğrencileri arasında çoğunluk (\%34) 5 saat ve üzerinde kullandıklarını belirtmiştir. Cinsiyete göre kız öğrencilerin internet kullanım süresinin yüksek olduğu göze çarparken okul türünde ise üniversite öğrencilerinin çoğunluğu göze çarpmaktadır.

Tablo 14: Öğrencilerin cinsiyet ve okul değişkenine göre internet kullanım amaçları

\begin{tabular}{|c|c|c|c|c|c|c|c|}
\hline \multirow{2}{*}{\multicolumn{2}{|c|}{$\begin{array}{c}\text { İnternet Kullanım } \\
\text { Amacı }\end{array}$}} & \multicolumn{2}{|c|}{ Cinsiyet } & \multirow{2}{*}{ Toplam } & \multicolumn{2}{|c|}{ Okul Türü } & \multirow[t]{2}{*}{ Toplam } \\
\hline & & $\mathrm{K}_{1 \mathrm{Z}}$ & Erkek & & Lise & Üniversite & \\
\hline \multirow{3}{*}{ Haber /e posta } & Sayı & 11 & 32 & 43 & 19 & 24 & 43 \\
\hline & Satır & $\% 25,6$ & $\% 74,4$ & $\% 100$ & $\% 44,2$ & $\% 55,8$ & $\% 100$ \\
\hline & Sütun & $\% 3,3$ & $\% 11,9$ & $\% 7,1$ & $\% 6,6$ & $\% 7,6$ & $\% 7,1$ \\
\hline \multirow{3}{*}{$\begin{array}{l}\text { Dizi ya da } \\
\text { Film izleme }\end{array}$} & Sayı & 34 & 25 & 59 & 31 & 28 & 59 \\
\hline & Satır & $\% 57,6$ & $\% 42,4$ & $\% 100$ & $\% 52,5$ & $\% 47,5$ & $\% 100$ \\
\hline & Sütun & $\% 10,1$ & $\% 9,3$ & $\% 9,7$ & $\% 10,7$ & $\% 8,9$ & $\% 9,7$ \\
\hline \multirow{3}{*}{$\begin{array}{l}\text { Sosyal ağlara } \\
\text { bağlanma }\end{array}$} & Sayı & 231 & 146 & 377 & 166 & 211 & 377 \\
\hline & Satır & $\% 61,3$ & $\% 38,7$ & $\% 100$ & $\% 44,0$ & $\% 56$ & $\% 100$ \\
\hline & Sütun & $\% 68,8$ & $\% 54,1$ & $\% 62,2$ & $\% 57,2$ & $\% 66,8$ & $\% 62,2$ \\
\hline \multirow{3}{*}{$\begin{array}{l}\text { Araştırma- } \\
\text { Bilgi edinme }\end{array}$} & Say1 & 42 & 15 & 57 & 23 & 34 & 57 \\
\hline & Satır & $\% 73,7$ & $\% 26,3$ & $\% 100$ & $\% 40,4$ & $\% 59,6$ & $\% 100$ \\
\hline & Sütun & $\% 12,5$ & $\% 5,6$ & $\% 9,4$ & $\% 7,9$ & $\% 10,8$ & $\% 9,4$ \\
\hline \multirow{3}{*}{$\begin{array}{l}\text { Oyun/ } \\
\text { Müzik/ } \\
\text { Alışveriş }\end{array}$} & Say1 & 17 & 49 & 66 & 49 & 17 & 66 \\
\hline & Satır & $\% 25,8$ & $\% 74,2$ & $\% 100$ & $\% 74,2$ & $\% 25,8$ & $\% 100$ \\
\hline & Sütun & $\% 5,1$ & $\% 18,1$ & $\% 10,9$ & $\% 16,9$ & $\% 5,4$ & $\% 10,9$ \\
\hline \multirow{3}{*}{ Diğer } & Say1 & 1 & 3 & 4 & 2 & 2 & 4 \\
\hline & Satır & $\% 25$ & $\% 75$ & $\% 100$ & $50,0 \%$ & $\% 50$ & $\% 100$ \\
\hline & Sütun & $\% 0,3$ & $\% 1,1$ & $\% 0,7$ & $0,7 \%$ & $\% 0,6$ & $\% 0,7$ \\
\hline \multirow{4}{*}{ Toplam } & Say1 & 336 & 270 & 606 & 290 & 316 & 606 \\
\hline & Satır & $\% 55,4$ & $\% 44,6$ & $\% 100$ & $\% 47,9$ & $\% 52,1$ & $\% 100$ \\
\hline & Sütun & $\% 100$ & $\% 100$ & $\% 100$ & $\% 100$ & $\% 100$ & $\% 100$ \\
\hline & & \multicolumn{2}{|c|}{$\begin{array}{l}x^{2}=53,545 \\
\mathrm{P}=0,000\end{array}$} & $\begin{array}{l}=5 \\
0,05)\end{array}$ & \multicolumn{2}{|c|}{$\begin{array}{l}x^{2}=22,669 \\
\mathrm{P}=0,000\end{array}$} & $05)$ \\
\hline
\end{tabular}


Öğrencilerin internet kullanım amaçları ile cinsiyet değişkeni incelendiğinde anlamlı bir ilişkiye rastlanmıştır $(P<0,05)$. Öncelikle her iki cinsiyette de büyük çoğunluk $(\% 62,2)$ sosyal ağlara bağlanma amaçlı kullandıklarını belirtmişlerdir. İkinci sırada ise oyun, müzik/ alışveriş amaçlı kullanım $(\% 10,9)$ gelmektedir. Daha sonra \%9,7 ile dizi ya da film izleme, \%7,1 ile de haber/ e posta amaçlı kullanım gelmektedir.

Cinsiyete göre; "haber/ e posta” amaçlı kullanımda kız öğrenciler \%25,6, erkek öğrenciler \%74,4; "dizi ya da film izleme” amaçlı kullanımda kız öğrenciler \%57,6; erkek öğrenciler \%42,4; "sosyal ağlara bağlanma" amaçlı kullanımda kız öğrenciler \% 61,3; erkek öğrenciler \%38,7; “araştırma bilgi edinme” amaçlı kullanımda kız öğrenciler \% 73,7; erkek öğrenciler \%26,3; “oyun/ müzik/ alışveriş” amaçlı kullanımda kız öğrenciler \%25,8; erkek öğrenciler \%74,2 orana sahiptirler. Buna göre kız öğrenciler dizi ya da film izleme, sosyal ağlara bağlanma ve araştırma ve bilgi edinme amaçlı kullanımda erkek öğrencilerden daha yüksek orana sahipken, erkek öğrenciler ise haber/ e posta amaçlı ve oyun/ müzik/ alışveriş amaçlı kullanımda kız öğrencilerden daha yüksek orana sahiptirler.

Öğrencilerin internet kullanım amaçları ile okul türü değişkeni arasında da anlamlı bir ilişkiye rastlanmıştır $(\mathrm{P}<0,05)$. Öncelikle her iki eğitim seviyesinde de büyük çoğunluk $(\% 62,2)$ sosyal ağlara bağlanma amaçlı kullandıklarını belirtmişlerdir.

Okul türüne göre; "haber/ e posta" amaçlı kullanımda lise öğrencileri \%44,2; üniversite öğrencileri \%55,8; “dizi ya da film izleme” amaçlı kullanımda lise öğrencileri \%52,5; üniversite öğrencileri \%47,5; "sosyal ağlara bağlanma" amaçlı kullanımda lise öğrencileri \%44; üniversite öğrencileri \%56; "araştırma bilgi edinme" amaçlı kullanımda lise öğrencileri \%40,4; üniversite öğrencileri \%59,6; “oyun/ müzik/ alışveriş” amaçlı kullanımda lise öğrencileri \%74,2; üniversite öğrencileri \%25,8 orana sahiptirler. Buna göre lise öğrencileri “dizi ya da film izleme” ve "oyun/ müzik/ alışveriş" amaçlı kullanımda üniversite öğrencilerinden daha yüksek orana sahipken, üniversite öğrencileri ise "haber/ e posta", "sosyal ağlara bağlanma" ve "araştırma ve bilgi edinme" amaçlı kullanımda lise öğrencilerinden daha yüksek orana sahiptirler.

Tablo 15: Öğrencilerin cinsiyet ve okul değişkenine göre sosyal medya kullanma amaçları

\begin{tabular}{|c|c|c|c|c|c|c|c|}
\hline \multirow{2}{*}{\multicolumn{2}{|c|}{ Sosyal Medya Kullanma Amacı }} & \multicolumn{2}{|c|}{ Cinsiyet } & \multirow{2}{*}{ Toplam } & \multicolumn{2}{|c|}{ Okul Türü } & \multirow[t]{2}{*}{ Toplam } \\
\hline & & $\mathrm{K}_{1 \mathrm{Z}}$ & Erkek & & Lise & Üniversite & \\
\hline \multirow{3}{*}{ Güncel olayları takip etmek } & Say1 & 84 & 93 & 177 & 67 & 110 & 177 \\
\hline & Satır & $\% 47,5$ & $\% 52,5$ & $\% 100$ & $\% 37,9$ & $\% 62,1$ & $\% 100$ \\
\hline & Sütun & $\% 26,3$ & $\% 35,2$ & $\% 30,3$ & $\% 24,1$ & $\% 35,9$ & $\% 30,3$ \\
\hline \multirow{3}{*}{ Sohbet etmek / Eğlence/ Oyun } & Say1 & 89 & 76 & 165 & 94 & 71 & 165 \\
\hline & Satır & $\% 53,9$ & $\% 46,1$ & $\% 100$ & $\% 57,0$ & $\% 43,0$ & $\% 100$ \\
\hline & Sütun & $\% 27,8$ & $\% 28,8$ & $\% 28,3$ & $\% 33,8$ & $\% 23,2$ & $\% 28,3$ \\
\hline \multirow{3}{*}{ Zaman geçirmek } & Say1 & 134 & 78 & 212 & 103 & 109 & 212 \\
\hline & Satır & $\% 63,2$ & $\% 36,8$ & $\% 100$ & $\% 48,6$ & $\% 51,4$ & $\% 100$ \\
\hline & Sütun & $\% 41,9$ & $\% 29,5$ & $\% 36,3$ & $\% 37,1$ & $\% 35,6$ & $\% 36,3$ \\
\hline Yeni arkadaşlar bulmak & Say1 & 13 & 16 & 29 & 14 & 15 & 29 \\
\hline
\end{tabular}


Lise ve Üniversite Öğrencilerinin Medya Araçları Kullanımlarının

Karşılaştırmalı Analizi

\begin{tabular}{|c|c|c|c|c|c|c|c|}
\hline & $\begin{array}{l}\text { Satır } \\
\text { Sütun }\end{array}$ & $\begin{array}{c}\% 44,8 \\
\% 4,1\end{array}$ & $\begin{array}{c}\% 55,2 \\
\% 6,1\end{array}$ & $\begin{array}{c}\% 100 \\
\% 5\end{array}$ & $\begin{array}{c}\% 48,3 \\
\% 5\end{array}$ & $\begin{array}{l}\% 51,7 \\
\% 4,9\end{array}$ & $\begin{array}{c}\% 100 \\
\% 5\end{array}$ \\
\hline \multirow{3}{*}{ Diğer } & Sayı & \multirow{3}{*}{$\begin{array}{c}0 \\
\% 0,0 \\
\% 0,0\end{array}$} & \multirow{3}{*}{$\begin{array}{c}1 \\
\% 100 \\
\% 0,4\end{array}$} & \multirow{3}{*}{$\begin{array}{c}1 \\
\% 100 \\
\% 0,2\end{array}$} & \multirow{3}{*}{$\begin{array}{c}0 \\
\% 0,0 \\
\% 0,0\end{array}$} & \multirow{3}{*}{$\begin{array}{c}1 \\
\% 100 \\
\% 0,3\end{array}$} & \multirow{3}{*}{$\begin{array}{c}1 \\
\% 100 \\
\% 0,2\end{array}$} \\
\hline & Satır & & & & & & \\
\hline & Sütun & & & & & & \\
\hline \multirow{4}{*}{ Toplam } & Say1 & \multirow{3}{*}{$\begin{array}{c}320 \\
\% 54,8 \\
\% 100\end{array}$} & \multirow{3}{*}{$\begin{array}{c}264 \\
\% 45,2 \\
\% 100\end{array}$} & \multirow{3}{*}{$\begin{array}{c}584 \\
\% 100 \\
\% 100\end{array}$} & \multirow{3}{*}{$\begin{array}{c}278 \\
\% 47,6 \\
\% 100\end{array}$} & \multirow{3}{*}{$\begin{array}{c}306 \\
\% 52,4 \\
\% 100\end{array}$} & \multirow{3}{*}{$\begin{array}{c}584 \\
\% 100 \\
\% 100\end{array}$} \\
\hline & Satır & & & & & & \\
\hline & Sütun & & & & & & \\
\hline & \multicolumn{2}{|c|}{$\begin{array}{l}x^{2}=12,328 \\
\mathrm{P}=0, \mathbf{0 1 5}\end{array}$} & \multicolumn{2}{|c|}{$\begin{array}{l}\mathrm{df}=4 \\
(\mathrm{P}<0,05)\end{array}$} & \multicolumn{2}{|c|}{$\begin{array}{l}x^{2}=13,545 \\
\mathrm{P}=0,009\end{array}$} & $\begin{array}{l}\mathrm{df}=4 \\
(\mathrm{P}<0,05)\end{array}$ \\
\hline
\end{tabular}

Öğrencilerin sosyal medya kullanım amaçları incelendiğinde hem $\underline{\text { cinsiyet }}$ hem de $\underline{o k u l}$ türü değişkeni arasında anlamlı bir ilişkiye rastlanmıştır $(\mathrm{P}<0,05)$; Öncelikle her iki cinsiyette de çoğunluk $(\% 36,3)$ sosyal medyayı "zaman geçirmek” amaçlı kullanmaktadır. Daha sonra "güncel olayları takip etmek" $(\% 30,3)$ amaçlı kullanım gelmektedir.

Cinsiyete göre incelendiğinde; "Güncel olayları takip etmek" amaçlı kullanım kız öğrencilerde \%47,5; erkek öğrencilerde \%52,5; "sohbet etmek/ eğlence/ oyun” amaçlı kullanım kız öğrencilerde \%53,9; erkek öğrencilerde \%46,1; “zaman geçirmek” amaçlı kullanım kız öğrencilerde \%63,2; erkek öğrencilerde \%36,8; “arkadaşlarımın ne yaptığını kontrol etmek/ yeni arkadaşlar bulmak" amaçlı kullanım kız öğrencilerde \%44,8; erkek öğrencilerde \%55,2 oranına sahiptir. Buna göre kız öğrenciler sosyal medyayı daha çok sohbet, oyun, eğlence ve zaman geçirmek amaçlı kullanırken, erkek öğrenciler ise güncel olayları takip etmek ve yeni arkadaşlar bulmak amaçlı kullanmaktadır.

Okul türüne göre incelendiğinde; "Güncel olayları takip etmek" amaçlı kullanım lise öğrencilerinde \%37,9; üniversite öğrencilerinde \%62,1; Sohbet etmek / eğlence / oyun amaçl1 kullanım lise öğrencilerinde $\% 57$, üniversite öğrencilerinde $\% 43$; zaman geçirmek amaçlı kullanım lise öğrencilerinde $\% 48,6$, üniversite öğrencilerinde $\% 51,4$; yeni arkadaşlar bulmak lise öğrencilerinde $\% 48,3$, üniversite öğrencilerinde $\% 51,7$ oranına sahiptir. Buna göre üniversite öğrencileri sosyal medyada güncel olayları daha fazla takip ederken lise öğrencileri daha çok sohbet, oyun, eğlence amaçlı kullanmaktadır.

Tablo 16: Öğrencilerin sosyal medya kullanma sıklığı ve cinsiyet ilişkisi

\begin{tabular}{ll|c|c|c}
\hline \multirow{2}{*}{ Sosyal Medya Kullanma Sıklı̆̆ } & \multicolumn{2}{|c|}{ Cinsiyet } & \multirow{2}{*}{ Toplam } \\
\cline { 2 - 2 } \multirow{2}{*}{$\begin{array}{l}\text { Günde } \\
1 \text { saatten az }\end{array}$} & Sayı & 60 & 64 & 124 \\
\cline { 2 - 2 } & Satır & $\% 48,4$ & $\% 51,6$ & $\% 100$ \\
\cline { 2 - 2 } Günde & Sütun & $\% 17,9$ & $\% 23,8$ & $\% 20,5$ \\
1-2saat & Sayı & 117 & 102 & 219 \\
\cline { 2 - 2 } & Satır & $\% 53,4$ & $\% 46,6$ & $\% 100$ \\
\cline { 2 - 2 } Günde & Sütun & $\% 34,9$ & $\% 37,9$ & $\% 36,3$ \\
\hline
\end{tabular}




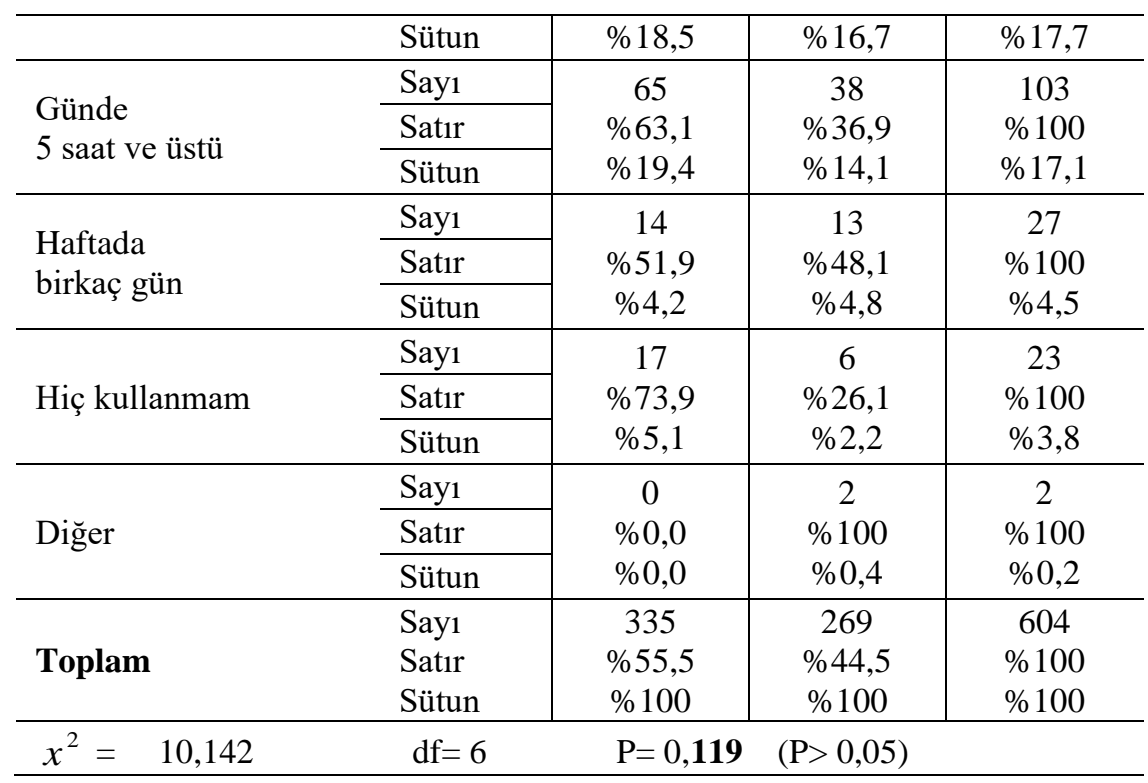

Öğrencilerin sosyal medya kullanma sıklığı ile cinsiyet ilişkisi incelendiğinde istatistiki olarak anlamlı bir ilişki olmadığı görülmektedir. Ancak tablo incelendiğinde her iki cinsiyetinde genel olarak \%36,3'ü günde 1-2 saat kullandıklarını belirtmişlerdir. Günde 1 saatten az kullananlar; kız öğrencilerde \%48,4, erkek öğrencilerde \%51,6; günde 1-2 saat kullananlarda kız öğrenciler \%53,4, erkek öğrenciler \%46,6; günde 3-4 saat kullananlarda kız öğrenciler \%57,9, erkek öğrenciler \%42,1; günde 5 saat ve üzerinde kullananlarda kı öğrenciler $\% 63,1$, erkek öğrenciler \%36,9; haftada birkaç gün kullananlarda kı öğrenciler \%51,9, erkek öğrenciler \%48,1 oranına sahiptir. Hiç sosyal medya kullanmayanların oranı ise kız öğrencilerde \%73,9 erkek öğrencilerde 26,1'dir. Buna göre günde 3-4 saat ve günde 5 saat ve üzerinde kullananlarda kız öğrencilerin oranı erkek öğrencilerden daha yüksektir. Kıran ve Eryılmaz'ın (2017: 95) üniversite öğrencilerine yaptıkları araştırmalarında da kadın öğrencilerin sosyal medyayı erkek öğrencilerden daha fazla kullandıkları saptanmıştır.

\section{Sonuç ve Tartışma}

Medya araçları kullanımı açısından lise ve üniversite öğrencileri arasında fark olup olmadığının araştırıldığı bu çalışmada genel anlamda her iki öğrenim türündeki gençler arasında medya kullanımının yoğun olduğu tespit edilmiştir. Buna göre her iki öğrenim türünde öğrencilerin internet kullanım alışkanlıkları televizyon kullanımlarından yüksek bulunmuştur. Lise ve üniversite öğrencilerinin yarısının geleneksel medya aracı olan televizyonu çoğunlukla dizi/film izlemek amacıyla kullandıkları görülmüştür. Cinsiyete göre en çok tercih edilen televizyon programlarında; kız öğrenciler ağırlıklı olarak eğlence/magazin/yarışma ve dizi/film programlarını tercih ederken; erkek öğrenciler ise haber/belgesel/tartışma, dini programlar ve spor programlarını tercih etmektedirler. Cinsiyete göre televizyon izleme sıklıkları 
Özgür KIRAN

Lise ve Üniversite Öğrencilerinin Medya Araçları Kullanımlarının

Karşılaştırmalı Analizi

incelendiğinde; kız öğrenciler çoğunlukla haftada birkaç gün, erkek öğrenciler ise günlük 1-2 saat izledikleri şeklinde görüş belirtmişlerdir. Okul türüne göre televizyon izleme sıklıklarında, her iki öğrenim düzeyindeki gençlerin çoğunluğu haftada birkaç gün izlediklerini belirtmişlerdir. Aksaçlıoğlu ve Yılmaz (2007:15) araştırmalarında öğrenciler için özellikle hafta sonları televizyona bağımlılık düzeylerinin yüksek olduğu, televizyonu 2 -3 saat izlemenin de fazla bulunduğu görülmektedir. Eryılmaz ve Çukurluöz (2018: 901) lise öğrencilerine yönelik dijital bağımlılık konulu araştırmalarında; öğrencilerin sosyal medya başta olmak üzere internet ve mobil telefonlarına bağımlı olduklarını ortaya koymuşlardır.

Öğrencilerin basılı gazeteleri takip etme alışkanlığının neredeyse hiç olmadığı ve internet üzerinden dahi gazete okuma alışkanlıklarının oldukça düşük olduğu söylenebilir. Televizyonun da bir nevi boş zaman geçirme aracı olduğu belirtilebilir. Günümüz gençleri dünyaya gözlerini açtıklarında yeni medya teknolojisiyle karşılaşmışlardır. Bu anlamda hız, hareket ve çeşitlilik içinde belli bir akıcıllığa sahip olan yeni medya araçları karşısında gazete, gençler açısından cazip bir medya aracı olarak görülmemektedir. Sosyal medyanın bireylerin haber edinme ihtiyacına da cevap verdiği düşünüldüğünde gençler için gazetelerin internet sayfalarından takibi önemsizleşmektedir. Aksaçlıoğlu ve Yılmaz (2007: 23) öğrencilerin boş zamanlarında, "kitap okumak", "televizyon izlemek", "bilgisayar kullanmak" faaliyetleri içinde kitap okumak en son tercih edilirken, ilk siralarda "bilgisayar kullanma" ile "televizyon izleme"yi tercih ettikleri saptanmıştır. Adler'e göre, bugün dijital dünyada büyüyen gençlerin birçoğu cep telefonsuz bir yaşam düşünememektedirler ve hiçbir zaman basılı gazete okumayabilirler. Bugünün okuyucuları daha kısa metinler okumayı istiyorlar. Günümüzde haberlerin hızı da geçmiştekinden çok daha hizlidır (Adler, 2008: 49-52).

İnternet kullanım amacına göre öğrencilerin yarıdan fazlasının yeni medya aracı olarak değerlendirilen sosyal ağlara bağlanmayı tercih ettikleri tespit edilmiştir. Genç ve arkadaşlarının üniversite öğrencileri üzerine yaptıkları araştırmaya göre katılımcıların yaklaşık dörtte üçü interneti sohbet etmek, oyun oynamak, film izlemek ve sosyal ağlarda gezinmek amaciyla kullanmaktadırlar (Genç, vd., 2018: 330). Sosyal medya kullanım sıklı̆̆ı incelendiğinde ise, çoğunluğu "günde 1-2 saat" kullandıklarını belirtmiştir. Babacan'ın (2017) araştırmasında \%80; Demir'in (2016) yaptığı araştırmada da \%66 oranlarıyla öğrencilerin sosyal medya kullanım sıklıkları araştırmamızla benzerlik taşımaktadır. Koç ve Tatı’nın (2017: 75-76) araştırmalarına göre öğrenciler çoğunlukla sosyal mecraları günlük 2-3 saat kullanmaktadırlar. Akyazı ve Tutkun'un (2013), üniversite öğrencilerinin sosyal ağları kullanım alışkanlıklarına göre sosyal mecraların gündelik kullanım sürelerini inceledikleri araştırmada, öğrencilerin üniversite türüne göre farklılaşmadıkları saptanmıştır. Devlet üniversitelerindeki gençlerin yarıya yakınının 
(\%47,2), günlük "1-3 saat arası" sosyal mecralara bağlandıkları, \%30,7'sinin ise, "1 saatten az" bağlandıkları saptanmıştır. Öte yandan, gençlerin günlük anlamda, \%14,7'si “3-5 saat arası”, \%5,5 gibi az oranda da "5 saatten fazla" sosyal mecralara bağlandıkları görülmüştür. Vakıf üniversitelerinde de (\%38,4'ü 1-3 saat, \%35,3'ü 1 saatten az, \%16,8'i 3-5 saat arası, \%6,8'i ise 5 saatten fazla) benzer sonuçlarla karşılaşılmaktadır. Aksaçlıoğlu ve Yılmaz (2007: 15) araştırmalarında bilgisayarı kullanmada ilk amaç "oyun oynamak” şeklinde ortaya çıkmıştır. Laura \& Richard (2004) hem ergen hem de yetişkin bireylerin sosyal medya üzerinden paylaşım yapmadıklarında kendilerinde eksiklik hissettiklerini belirtmişlerdir.

Öğrencilerin yine çoğunluğu sosyal medyayı "zaman geçirmek" amaçlı kullanmaktadırlar. Benzer araştırmalardan Demir’e (2016: 33) göre öğrenciler sosyal medyayı çoğunlukla $(\% 51,7)$ "zaman geçirme" amaçlı kullanırlarken bunu "online sohbet" $(\% 18,5)$ ile “arkadaş takibi” (\%10,9) izlemektedir. Koç ve Tatlı'ya (2017: 75-76) göre öğrencilerin \%31’i sosyal medyayı sohbet etmek, yeni arkadaşlar bulmak ve eğlenmek amacıyla kullanmaktadırlar. İnce ve Koçak'ın (2017: 743-744) araştırmasına katılanların çoğunluğu da "eğlenmek ve rahatlamak için" cevabını verirken, ikinci sırada, "arkadaşlarımla iletişimde bulunmak", üçüncü sırada ise "çeşitli konularda bilgi sahibi olmak için" yer almaktadır. Karaboğa'nın (2018) araştırmasında ise yine katılımcıların \%89'u sosyal medyayı arkadaş çevresiyle iletişime geçmek, \%84'ü sohbet etmek, \%71'i “oyun oynamak, eğlenmek ve zaman geçirmek” amaciyla kullandıklarını ifade etmişlerdir.

Öğrencilerin sosyal medya kullanımları ile cinsiyet değişkeni arasındaki ilişkide, kız öğrenciler sosyal medyayı daha çok sohbet, oyun, eğlence ve zaman geçirmek amaçlı kullanırken, erkek öğrenciler ise güncel olayları takip etmek ve yeni arkadaşlar bulmak amaçlı kullanmaktadır. Okul türü değişkeninde ise, üniversite öğrencileri sosyal medyada güncel olayları daha fazla takip ederken lise öğrencileri daha çok sohbet, oyun, eğlence amaçlı kullanmaktadır. İnce ve Koçak’ın (2017: 743-744) araştırmasına katılanların cinsiyetine göre; kadınlar erkeklere oranla bir oturumda daha uzun süre sosyal medya kullanmaktadır. Karaboğa'ya (2018: 923) göre, üniversiteli gençlerin günlük sosyal medya kullanım süreleri ise ortalama 4 saat $15 \mathrm{dk}$. dır. Yine üniversite öğrenimi gören kadınlar erkeklere göre sosyal mecralarda daha fazla zaman geçirmektedirler. Tanrıverdi ve Sağır (2014: 807), liseli erkek öğrencilerin kız öğrencilere göre sosyal medyayı daha fazla benimsediklerini buna karşın daha az başarılı olduklarını belirtmiştir.

Sosyal medyada en fazla kullanılan mecraların başında Instagram gelirken bunu Whatsapp, Facebook, Youtube ve Twitter takip etmektedir. Karaboğa'ya (2018) göre, üniversite öğrencilerinin çoğunluğu sırasıyla Instagram, Whatsapp, Youtube, Twitter ve Facebook kullanmaktadırlar. İnce ve Koçak'ın (2017: 743-744) araştırmasına katılanların yarıya yakını en fazla Facebook'da zaman harcadıklarını belirtmişlerdir. Bunu sırasıyla Twitter ve Instagram 
Özgür KIRAN

Lise ve Üniversite Öğrencilerinin Medya Araçları Kullanımlarının

Karşılaştırmalı Analizi

izlemektedir. Koç ve Tatlı'nın (2017: 81) araştırmalarına göre kadın öğrencilerin Facebook ve Twitter kullandıklarında erkek öğrencilere göre çevreleriyle iletişimlerini daha fazla kestikleri belirlenmiştir.

Araştırmamıza göre öğrencilerin çoğunluğu boş vakitlerini internetle geçirdiklerini, internete girerken genellikle cep telefonu kullandıklarını, internet kullanmaktan hem keyif aldıklarını hem de faydalı bulduklarını, yine gündeme dair haberleri internet üzerinden takip ettiklerini belirtmektedirler. Babacan'ın da (2017: 151) üniversite öğrencileri ile yaptığ araştırmada öğrencilerin yarıdan fazlasının $(\% 57,1)$ "her an” internete bağlı durumda oldukları sonucuna ulaşması araştırmamızla benzerlik taşımaktadır. Cinsiyete göre kız öğrencilerin internet kullanım süresinin yüksek oluşu dikkat çekerken, okul türünde ise üniversite öğrencilerinin çoğunluğu göze çarpmaktadır. Öner ve Çakır'ın (2019) araştırmalarında, internet bağımlılığı durumu cinsiyet ile karşılaştırıldığında erkek öğrencilerde bağımlılık düzeyinin kız öğrencilerden daha yüksek olduğu görülmüştür. Bu anlamda internet ve sosyal medya kullanımı arasında bir ilişki olduğu ortadadır. Öğrencilerin sosyal medya kullanımları ile internet bağımlılıkları arasında düşük fakat pozitif yönde anlamlı bir ilişki saptanmıştır. Bu sonuca göre öğrencilerin internet kullanımlarında önemli bir etkeninde sosyal medya olduğu söylenebilir.

Öğrencilerin internet kullanım amaçları ile cinsiyet değişkeni incelendiğinde kız öğrenciler dizi ya da film izleme, sosyal ağlara bağlanma ve araştırma/bilgi edinme amaçlı kullanımda erkek öğrencilerden daha yüksek orana sahipken, erkek öğrenciler ise haber/ e posta amaçlı ve oyun/ müzik/ alışveriş amaçlı kullanımda kız öğrencilerden daha yüksek orana sahiptirler. Öğrencilerin internet kullanım amaçları ile okul türü değişkeni arasında da her iki eğitim seviyesinde büyük çoğunluk $(\% 62,2)$ sosyal ağlara bağlanma amaçlı kullandıklarını belirtmişlerdir. Fakat lise öğrencileri "dizi ya da film izleme” ve "oyun/ müzik/ alışveriş" amaçlı kullanımda üniversite öğrencilerinden daha yüksek orana sahipken, üniversite öğrencileri ise "haber/ e posta" ve "araştırma ve bilgi edinme" amaçlı kullanımda lise öğrencilerinden daha yüksek orana sahiptirler. İnternetin kontrolsüzce çok fazla kullanılmasıyla bireylerde iletişim sorunları başta olmak üzere yeme-içme, uyku ve duruş bozuklukları, şiddet gibi bir takım psikososyal ve biyolojik sorunlar görülebilmektedir (Ertuğrul ve Keskin, 2012: 86).

Araştırma sonucundan hareketle şu önerilerde bulunulabilir; kullanım yaygınlığını her geçen gün artıran, maruz kalma yaşını doğum sonrasındaki ilk yıllara indiren medya araçları konusunda benzer araştırmalar sıklıkla ve farklı yaş kategorilerine yayılarak yapılmalıdır. Buna bağlı olarak özellikle çocuk ve gençlerin medyanın zararlı etkilerine karşı bilinçlendirilmesi konusunda bilinçli medya okuryazarlığı eğitimine nitelik yönünden ağırlık verilmesi de son derece önemlidir. Öyle ki medya kullanımında yasaklayıcı tutum bir çözüm olarak günümüzde 
anlamlı görülmemekte, bunun yerine hangi medya aracını hangi amaçlarla ne kadar kullanacağını bilen bireyler yetiştirilmesi yönünde çaba gösterilmesi daha faydalı olacaktır. Sorumluluğun yalnızca eğitim kurumlarına bırakılmaması, ilk sosyalleşme ortamı olan ailenin bu konuda öncelikli sorumlu toplumsal kurum olduğu göz önünde bulundurularak ebeveynlerin de bilinçli medya okuryazarlığı konusunda bilgi ve farkındalıklarını artırıcı çeşitli eğitim programları düzenlenmesi uygun olacaktır.

\section{Kaynakça}

Adler, R. P. (2008). Media policy and community values, R. P. Adler, D, Clark, K. Wallman (Ed). Media and Values kitabı içinde (s. 47-56). Wasington, DC.: The Aspen İnstitute Communication and Society Program Publication.

Aksaçlığlu, A. G. ve Yılmaz, B. (2007). Öğrencilerin televizyon izlemeleri ve bilgisayar kullanmalarının okuma alışkanlıkları üzerine etkisi. Türk Kütüphaneciliği 21 (1), 3-28.

Akyazı, E. ve Ünal, E. T. (2013). İletişim fakültesi öğrencilerinin amaç, benimseme, yalnızlık düzeyi ilişkisi bağlamında sosyal ağları kullanımı. Global Media Jornal Turksih Edition, 6 (3), 1-24.

Arslan, D. A. (2006). Bir sosyolojik olgu olarak televizyon. Uluslararası Insan Bilimleri Dergisi, $8(1), 1-17$.

Aytemiz, H. (2011). Bilinçli medya kullanımı. T.C. Aile ve Sosyal Politikalar Bakanlığı Aile ve Toplum Hizmetleri Genel Müdürlüğ̈̈ Yayınları.

Babacan, M. E. (2017). Sosyal medya ve gençlik. İstanbul: Bir Yayıncılık.

Baban, E. (2012). Mc Luhan ve Baudrillard'ın penceresinden sosyal medyanın etkisi: ifadenin esareti, gözetlenen toplum ve kayıp kimlik sendromu, T. Kara ve E. Özgen (Der.), Sosyal Medya Akademi kitabı içinde (s. 57-79). İstanbul: Beta Yayınları.

BTİK. Bilgi Teknolojileri ve İletişim Kurumu (2020, Şubat). We are social dijital pazar istatistikleri. Erişim adresi: https://wearesocial.com/blog/2019/04/the-state-of-digitalin-april-2019-all-the-numbers-you-need-to-know

Bilici, İ. E. (2017). Medya okuryazarlı̆̆ı ve eğitimi. Ankara: Nobel Yayınları.

Binark, M. (2007). Yeni medya çalışmalarında yeni sorular ve yöntem sorunu. M. Binark (Der.), Yeni Medya Çalışmaları kitabı içinde. Ankara: Dipnot Yayınları.

Can, N. (2015, Temmuz). Medya ve gençlik sorunları ilişkisi. Erişim adresi: https://www.ayk.gov.tr/wp-content/uploads/2015/01/CAN-Niyazi-MEDYA-VE-

GEN\%c3\%87L\%c4\%b0K-SORUNLARI\%c4\%b0L\%c4\%b0\%c5\%9eK\%c4\%b0S\%c4\%b0.pdf

Çetin Dağlı, M. ve Gündüz, B. (2017). Üniversite öğrencilerinde yalnızlık ve psikolojik iyi oluş ilişkisinde problemli internet kullanımının aracı rolü. Mehmet Akif Ersoy Üniversitesi Ĕ̈itim Fakültesi Dergisi, 44, 339-357.

Demir, Ü. (2016). Sosyal medya kullanımı ve aile iletişimi: Çanakkale'de lise öğrencileri üzerine bir araştırma. Selçuk İletişim, 9 (2), 27-50. 
Ertuğrul, İ. ve Keskin, N. (2012). İnternet'in Türkçe'nin yaygın kullanımında ve toplum-birey yapısının değişimindeki rolü. Internet Uygulamaları ve Yönetimi Dergisi, 3 (2), 79-88.

Eryazar, K. (2018, Aralık), Türkiye'de ve dünyada sosyal medya raporu. Erişim adresi:http://www.farklibirbakis.com/turkiyede-ve-dunyada-sosyal-medya-raporu/

Eryılmaz, S. ve Çukurluöz, Ö. (2018). Lise Öğrencilerinin dijital bağımlılıklarının incelenmesi: Ankara ili, Çankaya ilçesi örneği. Elektronik Sosyal Bilimler Dergisi, 17(67), 889-912.

Fiore, Q. (2019). Yaradanımız medya. (Ü. Oskay, Çev). İstanbul: Nora Yayınları.

Genç, Y., Durğun, A., Kara, H. Z. ve Çakır, R. (2018). İnternet kullanımının üniversite öğrencilerinin yalnızlık algılarına etkileri. Akademik Incelemeler Dergisi, 13 (2), 301336.

İnce, M. ve Koçak, M. C. (2017). Üniversite öğrencilerinin sosyal medya kullanım alışkanlıkları: Necmettin Erbakan Üniversitesi örneği. Karabük Üniversitesi Sosyal Bilimler Enstitüsü Dergisi, 7 (2), 736-749.

Jols, T. ve Thoman, E. (2008). 21. Yüzyıl okuryazarlı̆̆ı. Ankara: Ekinoks Yayınları.

Karaboğa, M. T. (2018). Üniversite öğrencilerinin bir sosyalleşme alanı olarak sosyal medya hakkındaki görüşleri. Mersin Üniversitesi Eğitim Fakültesi Dergisi, 14 (3), 912-936.

Kıran, Ö. ve Eryılmaz, Ç. (2018). Üniversite öğrencilerinde medya araçlarını kullanım alışkanlıkları: Sinop Üniversitesi örneği, Ö. Kıran (Ed.), Sosyal Bilimciler Gözüyle Sinop kitabı içinde (s.329-354). Ankara: Berikan Yayınları.

Koç, B. ve Tatlı, H. (2017). Üniversite öğrencilerinin sosyal ağ sitelerine yönelik tutum ve davranışları. Bingöl Üniversitesi Sosyal Bilimler Enstitüsü Dergisi, 7 (13), 71-82.

Laughey, D. (2010). Medya çalışmaları; teoriler ve yaklaşımlar, (A. Toprak, Çev.), İstanbul: Kalkedon Yayınları.

Laura, A. N. ve Richard, N. (2004). Development of a pyschometrically sound internet addiction scale: a preliminary step. Pyschology of Addictive Behaviors, 18 (4), 381-384.

Livingstone, S. (2016). Gençliğe ilişkin içerik oluşturmada riskli firsatları değerlendirmek. H. Hülür ve C. Yaşın (Ed.), Yeni Medya: Kullanıcının Yükselişi kitabı içinde, (s. 85-107). Ankara: Ütopya Yayınları.

Öner, İ. E. ve Çakır, R. (2019). Ortaokul öğrencilerinin internet bağımlılı̆̆ı ve sosyal medya kullanma düzeyleri arasındaki ilişkinin incelenmesi, Ahmet Keleşoğlu Ĕgitim Fakültesi Dergisi, 1 (1), 33-34.

Peltekoğlu, B. F. (2012). Sosyal medya sosyal değişim, T. Kara ve E. Özgen (Der.), Sosyal Medya Akademi kitabı içinde, (s. 3-8). İstanbul: Beta Yayınları.

Sinop Valiliği (2019, Ocak). Erişim adresi: https://www.sinop.gov.tr/eğitim

Şahin, A. (2018). Eleştirel medya okuryazarlığı. Ankara: Anı Yayınları.

Tanrıverdi, H. ve Sağır, S. (2014). Lise öğrencilerinin sosyal ağ kullanım amaçlarının ve sosyal ağları benimseme düzeylerinin öğrenci başarısına etkisi, Adlyaman Üniversitesi Sosyal Bilimler Enstitüsü Dergisi, 7 (18), 775-822. 
Ünür, E. (2016). Geleneksel medya'nın sosyal medyayı nasıl kullandığına ilişkin bir inceleme: dizilerin twitter kullanımı. Türkiye Sosyal Araştırmalar Dergisi, 20 (1), 153-170. 